\title{
Hydrogeochemical Characteristics of Hot Springs and Their Short-Term Seismic Precursor Anomalies along the Xiaojiang Fault Zone, Southeast Tibet Plateau
}

\author{
Chenhua Li ${ }^{1,2,3}$, Xiaocheng Zhou ${ }^{4, *}$, Yucong Yan ${ }^{4}$, Shupei Ouyang ${ }^{4}$ and Fengli Liu ${ }^{4}$ \\ 1 State Key Laboratory of Environmental Geochemistry, Institute of Geochemistry, Chinese Academy of \\ Sciences, Guiyang 550081, China; lichdzj@163.com \\ 2 University of Chinese Academy of Sciences, Beijing 100049, China \\ 3 Gansu Lanzhou Geophysics National Observation and Research Station, Lanzhou 730000, China \\ 4 United Laboratory of High-Pressure Physics and Earthquake Science, Key Laboratory of Earthquake \\ Prediction, Institute of Earthquake Forecasting, CEA, Beijing 100036, China; yanyucong2020@163.com (Y.Y.); \\ ouyangshupei888@163.com (S.O.); liufengli9723@163.com (F.L.) \\ * Correspondence: zhouxiaocheng188@163.com
}

Citation: Li, C.; Zhou, X.; Yan, Y.; Ouyang, S.; Liu, F. Hydrogeochemical Characteristics of Hot Springs and Their Short-Term Seismic Precursor Anomalies along the Xiaojiang Fault Zone, Southeast Tibet Plateau. Water 2021, 13, 2638. https://doi.org/ 10.3390/w13192638

Academic Editor: Domenico Cicchella

Received: 3 September 2021

Accepted: 23 September 2021

Published: 25 September 2021

Publisher's Note: MDPI stays neutral with regard to jurisdictional claims in published maps and institutional affiliations.

Copyright: (c) 2021 by the authors. Licensee MDPI, Basel, Switzerland. This article is an open access article distributed under the terms and conditions of the Creative Commons Attribution (CC BY) license (https:// creativecommons.org/licenses/by/ $4.0 /)$.

\begin{abstract}
Significant hydrogeochemical changes may occur prior- and post-earthquakes. The Xiaojiang fault zone (XJF), situated in a highly deformed area of the southeastern margin of the Tibetan Plateau, is one of the active seismic areas. In this study, major and trace elements, and hydrogen and oxygen isotopes of 28 sites in hot springs along the XJF were investigated from June 2015 to April 2019. The meteoric water acts as the primary water source of the hot spring in the XJF and recharged elevations ranged from 1.8 to $4.5 \mathrm{~km}$. Most of the hot spring water in the study area was immature water and the water-rock reaction degree was weak. The temperature range was inferred from an equation based on the $\mathrm{SiO}_{2}$ concentration and chemical geothermal modeling: $24.3 \sim 96.0^{\circ} \mathrm{C}$. The circulation depth for the springs was estimated from 0.45 to $4.04 \mathrm{~km}$. We speculated the meteoric water firstly infiltrated underground and became heated by heat sources, and later circulated to the earth's surface along the fault and fracture and finally constituted hot spring recharge. Additionally, a continuous monitoring was conducted every three days in the Xundian hot spring since April 2019, and in Panxi and Qujiang hot springs since June 2019. There were short-term (4-35 d) seismic precursor anomalies of the hydrochemical compositions prior to the Xundian $M_{\mathrm{L}} 4.2$, Dongchuan $M_{\mathrm{L}} 4.2$, and Shuangbai $M_{\mathrm{L}} 5.1$ earthquakes. The epicentral distance of anomalous sites ranged from 19.1 to $192.8 \mathrm{~km}$. The anomalous amplitudes were all over 2 times the anomaly threshold. The concentrations of $\mathrm{Na}^{+}, \mathrm{Cl}^{-}$, and $\mathrm{SO}_{4}{ }^{2-}$ are sensitive to the increase of stress in the XJF. Modeling on hydrology cycles of hot springs can provide a plausible physicochemical basis to explain geochemical anomalies in water and the hydrogeochemical anomaly may be useful in future earthquake prediction research of the study area.
\end{abstract}

Keywords: hot spring; isotopes; hydrogeochemistry; earthquake; Xiaojiang fault zone

\section{Introduction}

Significant hydrogeochemical changes may occur prior to earthquake, co-seismic, and post-earthquake, including the short-term hydrogeochemical changes [1-23]. Some changes have been properly documented and interpreted as potential seismic precursors, including fossil instances of seismic precursors [24,25], such as hydrogeochemical precursors of strong earthquakes that were previously documented in northern Iceland and central Italy [1,26].

The geochemical anomalies may be mainly caused by the alteration of groundwater in the specific circulating system under the action of increasing crustal stress before and after the earthquakes; however, how and where these groundwaters originate, and how they migrate towards, along, and away from fault zones during the seismic cycle is unknown $[27,28]$. The increasing importance of the earthquake-related groundwater 
in the science of seismic precursors makes an understanding of the origin and migration pathways of groundwater of paramount importance in addressing societal challenges such as seismic hazard mitigation $[1,11,26,29]$.

The Xiaojiang fault zone (XJF), situated in a highly deformed area of the southeastern margin of the Tibetan Plateau, is one of the active seismic areas (Figure 1a). The Xiaojiang fault system extends in the north-south direction about $700 \mathrm{~km}$ (Figure 1b) and consists of early to middle Paleozoic crystalline rocks and Sinian to Triassic sedimentary rocks [30,31]. The XJF is very active, along which four strong earthquakes with magnitude $>7.0$ have occurred since 1500 A.D. [13,32], including the Yiliang Ms7.0 earthquake in 1500, the Dongchuan $M s 7^{3} / 4$ earthquake in 1733, the Huaning Ms7.0 earthquake in 1789, and the Songming Ms8.0 earthquake in 1833. The measure of soil gas concentrations near the XJF were conducted, and it was found that the faults could act as channels for gas migration and the fault activity enhanced permeability and increased the emission rates of the gases [33]. Previous studies on geochemical characteristics of hot spring fluids at the Xiaojiang fault showed $\mathrm{CO}_{2}$ fluids containing $\delta^{13} \mathrm{C}_{\mathrm{CO} 2}(-16.6 \%$ - $23.6 \%)$ mainly came from a mix source among biogenic (mean: $-25 \%$ ), mantle (-8\%o - $4.7 \%$ ), metamorphic (mean: $0 \%$ ), and meteoric origin $(-8.5 \%$ - $6 \%$ ), while hot spring water recharge mainly came from meteoric waters [34]. This region is of critical research value for geochemical monitoring of hot spring fluids. Thus far, the mechanism of geochemical changes and the migration model of groundwater at Xiaojiang fault are poorly known as yet.

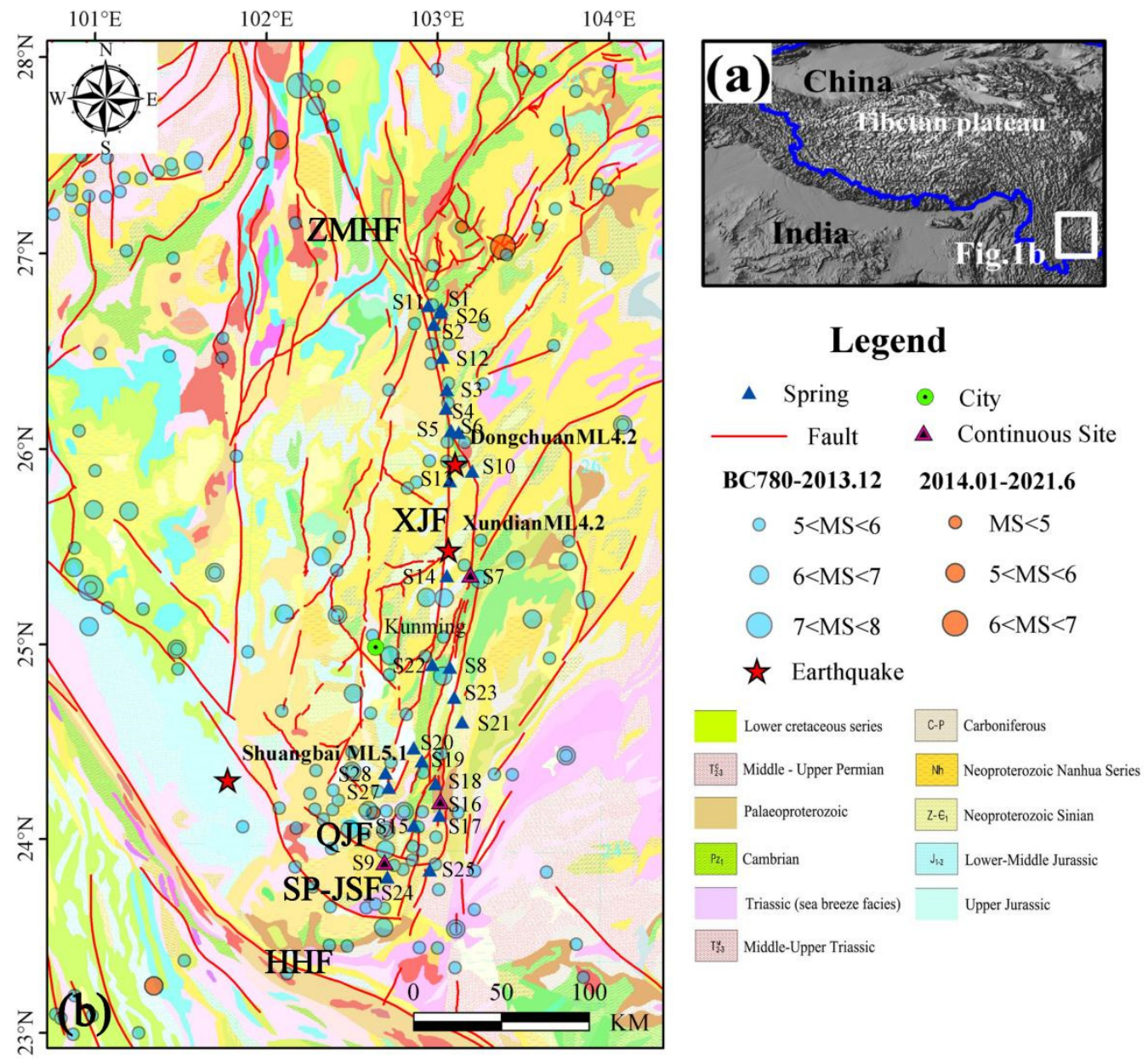

Figure 1. The plot of sampling site distribution: (a) localization of the area of this study; (b) geological map in the XJF. Red stars correspond to earthquakes that occurred during continuous monitoring near the continuous monitoring sites. XJF: Xiaojiang fault; HHF: Honghe fault; QJF: Qujiang fault; SP-JSF: Sinping-Jianshui fault; ZMHF: Zemuhe fault. 
In our study, the hot springs near to the XJF were investigated five times from December 2015 to April 2019. A continuous monitoring was conducted every three days in the Xundian hot spring since April 2019, and in Panxi and Qujiang hot springs since June 2019, where we studied the geochemical and time-spatial changes of hot spring waters in the XJF. Here, we also reported the hydrogeochemical anomalies of hot springs detected prior to the 2020 Xundian earthquake $\left(M_{\mathrm{L}} 4.2\right)$, the 2020 Dongchuan earthquake $\left(M_{\mathrm{L}} 4.2\right)$, and the 2021 Shuangbai earthquake $\left(M_{\mathrm{L}} 5.1\right)$. We tried to understand the physical processes behind the anomalies, by carrying out a model on hydrology cycles of hot springs. We discussed the coupling mechanism of fluids from deep and shallow parts inside the fault zone and the association between the changes of geochemical characteristics of hot spring fluids and the earthquakes. These studies were then followed by geochemical modeling and statistical studies to explain and verify previous interpretations [35].

\section{Geological Setting}

The active Xiaojiang fault zone, which is escaping southeastward from the Tibet Plateau and rotating around the Eastern Himalayan Syntaxis, is located in Yunnan Province of southwestern China (Figure 1a). It connects with the Zemuhe fault to the north [36] and is juxtaposed by the Red River strike-slip fault to the south [37]. As a zone of intense seismic activity at the east boundary of the Chuan-Dian rhombic block, the XJF shows the left-strike-slip kinetic properties and runs north to south (Figure 1b). A wide crushed zone and a series of Neozoic lignite graben basins formed along the fault. The active XJF zone has a complicated structure and can be divided into three sections based on geometric features (Figure 1b). The northern section extends from Qiaojia to Menggu, trends in the $\mathrm{N}-\mathrm{S}$ direction and is roughly $50 \mathrm{~km}$ long. For the part north of Huaning of this fault zone, the average sinistral strike-slip rate at the late Pleistocene Epoch-Holocene Epoch was 8-9 mma m $^{-1}$ [38] and $9.69 \mathrm{mma}^{-1}$ in the recent 500-year period [39], while that during 1999-2007 was 8-10 $\mathrm{mma}^{-1}$ according to GPS measurements. The sliding rate magnitudes determined with different methods were roughly the same. The middle section from Menggu to Chenjiang is composed of two roughly N-S trending left-lateral strike-slip faults, namely the eastern and the western branches of the XJF. The left-lateral strike-slip rate along the eastern branch is up to $9 \mathrm{mma}^{-1}$, and that along the western branch is 7 $\mathrm{mma}^{-1}$. The southern segment from Chenjiang to Shanhua, approximately $150 \mathrm{~km}$ long and $25 \mathrm{~km}$ wide, is a braid-shaped fault belt. It forms a southward extension of the eastern branch of the Xiaojiang fault zone. Since the early Neozoic Era, with the formation of the Sichuan-Yunnan active block and its proactive sliding movement toward SE-SSE [40,41], the Xiaojiang fracture zone became the southern part of the southeast boundary of this block and showed strong left-lateral strike-slip motion with the west disc as the driving disc. With such high-speed activity, the Xiaojiang fault zone becomes the fault zone most frequently attacked by earthquakes in Yunnan. In the latest 500 years, 16 earthquakes with $M \geq 6$ happened there, including 4 earthquakes with $M \geq 7$ and 1 earthquake of $M 8$. The fracture of these earthquakes has fully covered this fault zone.

Most of fractures are developed in Paleozoic sedimentary rock deposits, and some in Mesozoic and Neozoic strata. Hot springs in this area are not distributed equally, with most of which are exposed along the Xiaojiang fault zone, especially exposed in the junction between the Qujiang-Shiping fault zone and the southern part of the Xiaojiang fault zone. It is mostly exposed in the Mesozoic, the Paleozoic, and the Sinian strata, enclosed by carbonate rocks, limestones, sandstones, and other sedimentary rocks [42]. The generation and migration of hot springs are strictly controlled by tectonic activities and closely associated with the intensity and scale of modern activities of the fault zone. The water temperatures of most hot springs are below $60^{\circ} \mathrm{C}$, and a few hot-temperature springs are available (the highest water temperature is $72{ }^{\circ} \mathrm{C}$ only). 


\section{Sampling and Analyzing Methods}

Samples of groundwater were collected repeatedly from 28 sites of hot springs and wells along the XJF in June 2015, January 2016, February 2017, March 2018, and April 2019 , respectively (Figure $1 \mathrm{~b}$ and Table S1). After filtration through $0.45 \mu \mathrm{m}$ membrane, samples were collected in five colorless polyethylene terephthalate (PET) bottles (50 mL) for major element concentration, trace elements concentration, hydrogen and oxygen isotopes, and $\mathrm{SiO}_{2}$ concentration analysis. The bottles were new and rinsed with the water that was being sampled, filtered before use, and then collected to avoid air space. The samples were acidified with ultrapure $\mathrm{HNO}_{3}$ for cation analysis, but not acidified for anion analyses. Samples were stored in a $4{ }^{\circ} \mathrm{C}$ refrigerator, with laboratory analyses carried out within two weeks of sampling. Specific conductance, $\mathrm{pH}$, dissolved oxygen, and temperature were measured in well water using a multiparameter probe inserted into a flow-through cell closed to the atmosphere, and in springs by lowering the probe into the spring vent for in situ measurements. The concentrations of cations $\left(\mathrm{K}^{+}, \mathrm{Na}^{+}, \mathrm{Mg}^{2+}\right.$, and $\left.\mathrm{Ca}^{2+}\right)$ and anions $\left(\mathrm{F}^{-}, \mathrm{Cl}^{-}, \mathrm{Br}^{-}, \mathrm{NO}_{3}{ }^{-}\right.$, and $\left.\mathrm{SO}_{4}{ }^{2-}\right)$ were measured by a Dionex ICS-900 ion chromatograph and an AS40 automatic sampler at the Earthquake Forecasting Key Lab of China Earthquake Administration, with the reproducibility within $\pm 2 \%$ and detection limits $0.01 \mathrm{mg} / \mathrm{L}$ [43]. The $\mathrm{HCO}_{3}{ }^{-}$and $\mathrm{CO}_{3}{ }^{2-}$ concentrations in the hot springs were measured by the $0.05 \mathrm{~mol} / \mathrm{L} \mathrm{HCl}$ titration $0.1 \%$ methyl orange and $1 \%$ phenolphthalein procedures with a ZDJ-100 potentiometric titrator (reproducibility within $\pm 2 \%$ ). The data were evaluated by the ion balance (ib) calculated according to Equation (1) [44].

$$
\% \text { difference }=100 \times \frac{\sum \text { cations }-\sum \text { anions }}{\sum \text { cations }+\sum \text { anions }}
$$

Trace elements were analyzed at the Test Center of the Research Institute of Uranium Geology by Element XR ICP-MS (Thermo Fisher, Bremen, Germany) [45]. In our study, 24 kinds of trace elements were measured, including iron group elements of Ti, V, Cr, $\mathrm{Fe}, \mathrm{Co}$, and $\mathrm{Ni}$, chalcophile elements of $\mathrm{Cu}, \mathrm{Zn}, \mathrm{Ag}, \mathrm{Cd}, \mathrm{Sn}, \mathrm{Sb}$, and $\mathrm{Pb}$, and other trace elements including $\mathrm{Li}, \mathrm{Be}, \mathrm{B}, \mathrm{Al}, \mathrm{Sr}, \mathrm{Mo}, \mathrm{Ba}, \mathrm{Tl}, \mathrm{Th}, \mathrm{U}$, and $\mathrm{Mn}$. Accuracy and precision of the measures were computed by analyzing certified reference materials and by performing several replicas and dilutions on samples; the relative errors were less than $10 \%$ for all analyzed elements. The hydrogen and oxygen isotopes were measured using a Finnigan MAT253 mass spectrometer, via the TC/EA method. Results were expressed as parts per thousand deviations from the Vienna Standard Mean Ocean Water (V-SMOW). Precisions of $\pm 0.2 \%$ (2S.D.) and $\pm 1 \%$ (2S.D.) were obtained for $\delta^{18} \mathrm{O}$ and $\delta \mathrm{D}$ in a standard water sample, respectively [46]. The inductively coupled plasma emission spectrometer Optima-5300 DV (PerkinElmer Inc.) was used to detect $\mathrm{SiO}_{2}$. The threshold value of continuous monitoring was calculated according to the equation $X+2 \sigma$ (X: average value; $2 \sigma$ : twice of variance). We also used change-point $(\mathrm{CP})$ analysis on the temporal series of continuous monitoring data. The specific method of joinpoint regression was shown in [47].

\section{Results}

Physical, chemical, and isotopic data for the water samples are reported in Tables S2-S4. The ion balances of all samples were less than 5\%, indicating credible analysis results for these samples. Groundwater in the study area exhibits a wide range of salinities, from 214 to $3010 \mu \mathrm{s} / \mathrm{cm}$. The $\mathrm{pH}$ in the spring waters was roughly neutral, with values ranging between 6.49 and 7.66, likely due to the underlying carbonaceous aquifer materials. The temperature of the spring waters in the XJF were in a range from 24 to $72.3^{\circ} \mathrm{C}$ and TDS values ranged from 200.24 to $1290.56 \mathrm{mg} / \mathrm{L}$. The main cations in hot springs were $\mathrm{Ca}^{2+}$ and $\mathrm{Mg}^{2+}$, while the main anions were $\mathrm{HCO}_{3}{ }^{-}$and $\mathrm{SO}_{4}{ }^{2-}$. The distribution of $\delta \mathrm{D}$ and $\delta^{18} \mathrm{O}$ in water samples was $-15.4 \%$ o $-9.90 \%$ and $-117.0 \%$ o $-74.0 \%$, respectively, while that of $\mathrm{SiO}_{2}$ concentration was $3.58 \sim 44.1 \mathrm{mg} / \mathrm{L}$. The concentration of trace elements was low, and mostly below $1 \mathrm{mg} / \mathrm{L}$ except for $\mathrm{B}, \mathrm{Fe}$, and $\mathrm{Sr}$. The concentrations of $\mathrm{Ca}^{2+}, \mathrm{Mg}^{2+}, \mathrm{Na}^{+}$, and $\mathrm{K}^{+}$ranged from $<0.01$ to $243.10 \mathrm{mg} / \mathrm{L}, 0.42$ to $179.20 \mathrm{mg} / \mathrm{L}, 1.93$ to $265.39 \mathrm{mg} / \mathrm{L}$, and 1.37 
to $40.11 \mathrm{mg} / \mathrm{L}$, respectively; the concentrations of $\mathrm{Cl}^{-}, \mathrm{SO}_{4}{ }^{2-}$, and $\mathrm{HCO}_{3}{ }^{-}$ranged from 0.63 to $150.78 \mathrm{mg} / \mathrm{L}, 3.53$ to $1147.38 \mathrm{mg} / \mathrm{L}$, and 12.17 to $729.03 \mathrm{mg} / \mathrm{L}$, respectively.

It was found that the major ions $\left(\mathrm{Na}^{+}, \mathrm{Cl}^{-}, \mathrm{SO}_{4}{ }^{2-}\right)$ showed large and frequent fluctuations prior to some earthquakes, but no clear regular changes were found in the major ions $\left(\mathrm{HCO}_{3}{ }^{-}, \mathrm{Ca}^{2+}, \mathrm{Mg}^{2+}\right)$, indicating that the anion $\mathrm{HCO}_{3}{ }^{-}$and cations $\mathrm{Ca}^{2+}$ and $\mathrm{Mg}^{2+}$ are extremely unstable and may lead to deposits easily. In our case, the average value of concentration was taken as the background level (x) and the average plus/minus two standard deviations as the abnormal threshold value in the hydrochemical composition. Results of continuous monitoring on the change of hydrochemical compositions of Xundiantangzi hot spring (S7) showed the background mean value of $\mathrm{Na}^{+}, \mathrm{Cl}^{-}, \mathrm{SO}_{4}{ }^{2-}$, and TDS were 124.59, $18.13,479.44$, and $1281.89 \mathrm{mg} / \mathrm{L}$, respectively. Results of continuous monitoring on the change of hydrochemical compositions of Panxi hot spring (S16) showed the background mean value of $\mathrm{Na}^{+}, \mathrm{Cl}^{-}, \mathrm{SO}_{4}{ }^{2-}$, and TDS were 9.74, 6.01,31.22, and $415.58 \mathrm{mg} / \mathrm{L}$, respectively. Results of continuous monitoring on the change of hydrochemical compositions of Qujiang hot spring (S9) showed the background mean value of $\mathrm{Na}^{+}, \mathrm{Cl}^{-}, \mathrm{SO}_{4}{ }^{2-}$, and TDS were 268.34, 5.86, 20.06, and $670.91 \mathrm{mg} / \mathrm{L}$, respectively (Table S5).

\section{Discussion}

\subsection{Origin of Hot Spring Water}

We measured hydrogen isotopes $(\delta \mathrm{D})$, oxygen isotopes $\left(\delta^{18} \mathrm{O}\right)$, and concentrations of dissolved major elements in groundwater sampled in hot springs along the XJF. Results showed that hot spring isotopic ratios ranged from $-15.4 \%$ to $-9.90 \%$ for $\delta \mathrm{D}$ and from $-117.0 \%$ to $-74.0 \%$ for $\delta^{18} \mathrm{O}$ (V-SMOW). The majority of the water samples were distributed near to the local meteoric water line (LMWL) of the Kunming $\delta \mathrm{D}=6.56 \delta^{18} \mathrm{O}-2.96$ $\left(R^{2}=0.91, n=151\right)$ [48], indicating that the spring waters were mainly originated from meteoric water [49-51] (Figure 2). Nanpan river that is the main river along the XJF with $\delta \mathrm{D}$ mean of $-69.7 \%$ and $\delta^{18} \mathrm{O}$ mean of $-9.3 \%$ plots on the GMWL. Groundwater was induced by precipitation recharging from high altitude regions. Aquifer rocks dissolved in the infiltrating water and freshening started, consisting of cation exchange during groundwater flow. The values of $\delta \mathrm{D}$ and $\delta^{18} \mathrm{O}$ of springs from high mountain areas were more negative, while the river water values collected in lower altitude regions were less negative, which is constant with the previous results $[41,50]$. According to the relation between the oxygen isotope and the recharging elevation $\left(\delta^{18} \mathrm{O}=-0.002 \mathrm{ALT}-6.327\right)$ [52], the recharging elevation is calculated to be about $1.8 \sim 4.5 \mathrm{~km}$.

\subsection{Origin of Water-Soluble Ions in Hot Springs}

\subsubsection{Origin of Major Elements}

The proportions of cationic $\left(\mathrm{K}^{+}+\mathrm{Na}^{+}, \mathrm{Mg}^{2+}\right.$, and $\left.\mathrm{Ca}^{2+}\right)$ and anionic $\left(\mathrm{Cl}^{-}, \mathrm{SO}_{4}{ }^{2-}\right.$, and $\mathrm{HCO}_{3}{ }^{-}$) concentrations of water samples from the 28 sites are shown in Figure 3. The distribution of anions and cations of the hot spring water samples indicated that $\mathrm{Ca}^{2+}$, $\mathrm{Mg}^{2+}, \mathrm{HCO}_{3}{ }^{-}$, and $\mathrm{SO}_{4}{ }^{2-}$ were the main chemical compositions for most of the samples (Figure 3). The hot spring samples have different total ionic salinity, TIS, as indicated by the correlation plot of $\mathrm{SO}_{4}{ }^{2-}+\mathrm{HCO}_{3}{ }^{-}$vs. $\mathrm{Cl}^{-}$[54] (Figure 4). In this study, mostly spring waters have much lower TIS $(<26 \mathrm{meq} / \mathrm{kg})$. Major elements showed that hot springs presented complicated compositions consistent with previous studies [34] (Table S2). The salinities increase progressively as the hot spring water becomes more $\mathrm{SO}_{4}-\mathrm{Mg}$ dominant, accompanied by $\mathrm{SO}_{4}-\mathrm{Mg}(\mathrm{Na}, \mathrm{Ca})$-type water (Table S2 and Figures 3 and 4). Spatially, most hot springs are $\mathrm{HCO}_{3}-\mathrm{Ca}(\mathrm{Mg})$, and the water samples (S6, S9, S14, S24) with $\mathrm{HCO}_{3}$ $\mathrm{Na}$ water are distributed mainly at the southern segment of the fault zone; the water samples (S1, S8, S12, S26) with $\mathrm{SO}_{4}-\mathrm{Mg}(\mathrm{Ca})$ water are mainly distributed in the northern segment of the fault zone; and other water samples (S3, S5, S18, S20, S22) are the mixture of several end-members. 


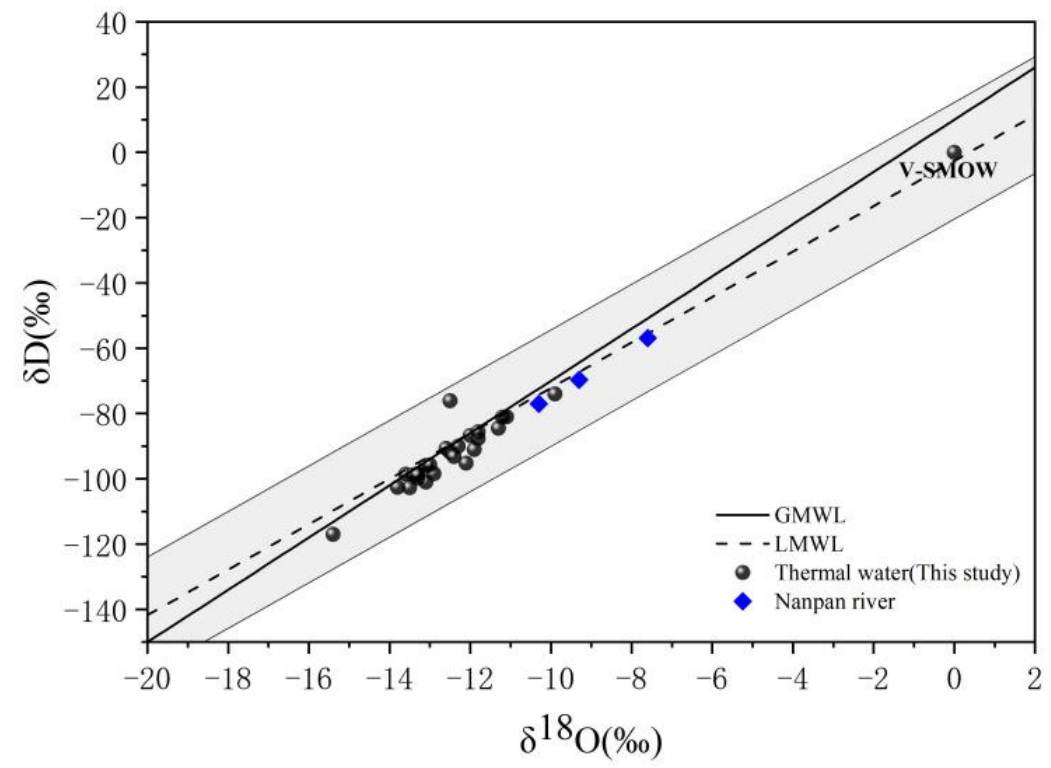

Figure 2. Plot of $\delta \mathrm{D}$ versus $\delta^{18} \mathrm{O}$ for the hot springs and stream waters.( The Global Meteoric Water Line (GMWL) from Craig (1961). The local meteoric water line (LMWL) [48] is shown for reference with the prediction interval (shaded area; $\delta \mathrm{D}= \pm 17.88 \%$ ) [53]).

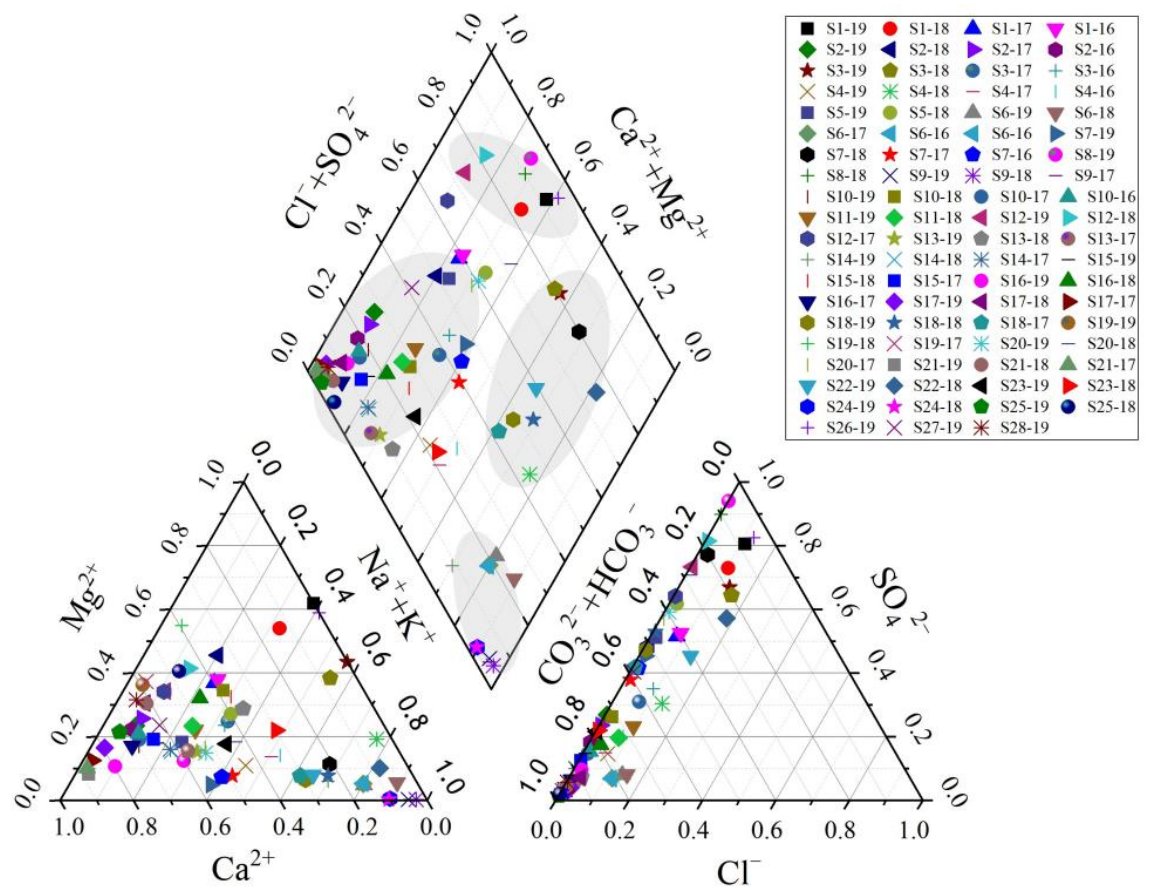

Figure 3. Piper diagram showing major ion chemistry of the sampled points. 


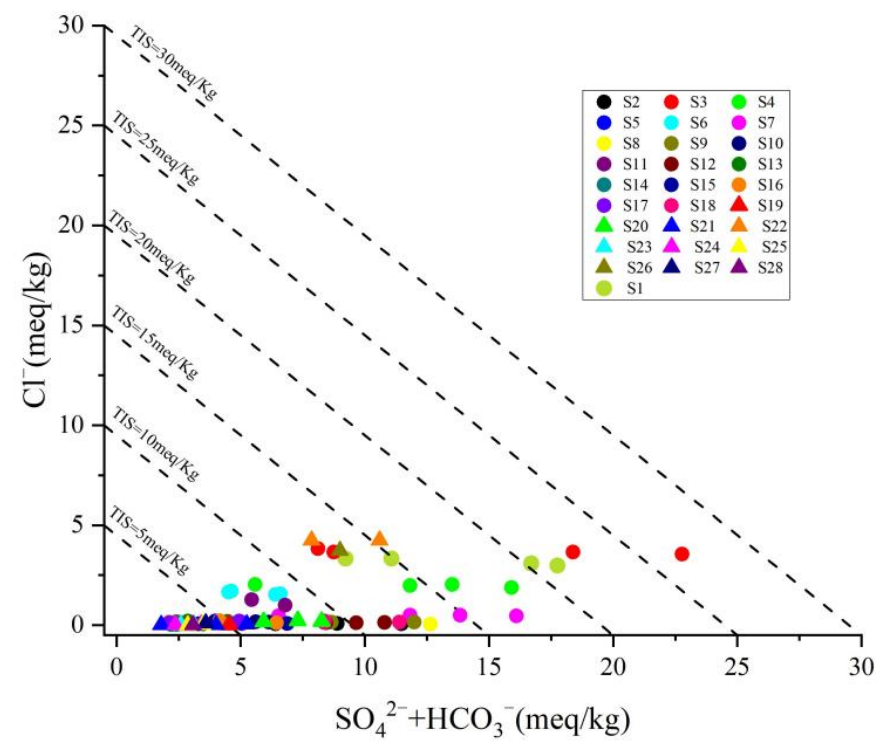

Figure 4. Correlation plot of $\mathrm{SO}_{4}{ }^{2-}+\mathrm{HCO}_{3}{ }^{-} \mathrm{vs}$. $\mathrm{Cl}^{-}$for the hot springs of the $\mathrm{XJF}$, also showing isolines of total ionic salinity (TIS) lines for reference.

Congruent as well as incongruent dissolution of aquifer rocks, hydrothermal conditions, and hydrodynamic power, together with cation exchange reactions may strongly influence the ionic concentration and facies types of the groundwater in the aquifer along the XJF. In the study area, carbonate rocks are mainly developed and $\mathrm{HCO}_{3}{ }^{-}$in hot springs mainly comes from carbonates, while $\mathrm{Ca}^{2+}$ and $\mathrm{Mg}^{2+}$ mainly come from soluble limestone $\left(\mathrm{CaCO}_{3}\right)$ and dolomites $\left(\mathrm{MgCO}_{3}\right)$ dissolved by the groundwater. In addition, the Tertiary coal bed (lignite), which is embedded along the XJF, contains a large amount of sulfides. The oxidation of sulfides results in the massive invasion of $\mathrm{S}$, which can be hardly dissolved in water into the underground water as $\mathrm{SO}_{4}{ }^{2-}$ [55]. As a result, underground water flowing through this kind of strata is mainly represented by $\mathrm{SO}_{4}{ }^{2-}$ and shows features of acid geothermal water. In addition to dolomites, limestone, and carbonate rocks, shales, sandstones, and conglomerates are also developed in the study area, mainly including quartz, mica, feldspar, and other aluminosilicate minerals, etc. Under high temperature and high pressure, the recycled water has a water-rock reaction with aluminosilicate and carbonate rocks, making the $\mathrm{Na}^{+}$, silicic acid, and carbonates in surrounding rocks enter into water in huge amounts [41]. Meanwhile, the $\mathrm{Na}^{+}$-containing salts can hardly be dissolved but get migrated and gathered easily. In view of distribution, sodium bicarbonate waters are mainly gathered in the southern part of the fault zone, while calcium magnesium sulfate waters gather in the northern part; most of the remaining parts are occupied by calcium magnesium carbonate waters.

\subsubsection{Origin of Trace Elements}

Analysis results of trace elements in a set of representative samples are shown in Table S3. For comparing trace element patterns between different types of waters, we used enrichment coefficients normalized by titanium as a less mobile element analyzed in both waters and rock samples: $\mathrm{EF}_{\mathrm{i}}=\left(\mathrm{C}_{\mathrm{i}} / \mathrm{T}_{\mathrm{i}}\right)_{\mathrm{w}} /\left(\mathrm{C}_{\mathrm{i}} / \mathrm{T}_{\mathrm{i}}\right)_{\mathrm{r}}$, where subscripts $\mathrm{w}$ and $\mathrm{r}$ relate to water and rock, respectively (see [56] for the Ti choice). The spring waters of the XJF are compared with the corresponding Emeishan basalts in the Dongchuan (Figure 5). Rock chemistry is taken from Chen et al. [57]. The $\mathrm{EF}_{\mathrm{i}}$ of trace elements in hot spring waters are associated with regional mineral rocks and reflect the degree of water-rock action to a certain extent. 


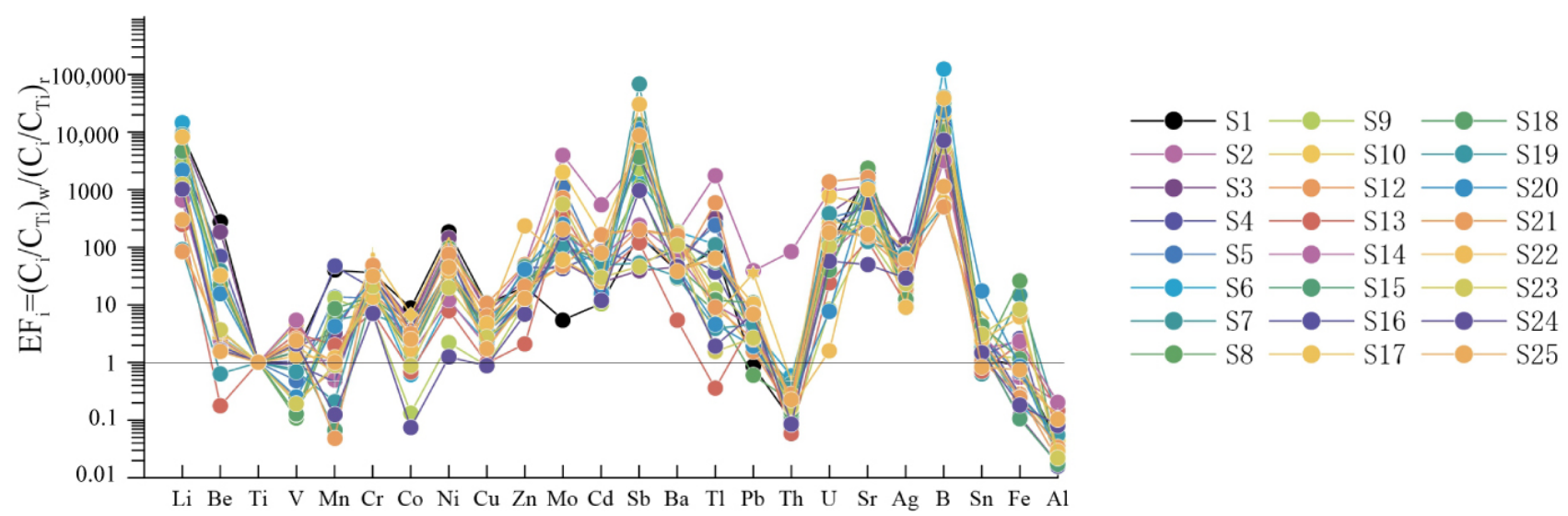

Figure 5. Trace element distribution in terms of enrichment coefficient (weight ratios) normalized to Ti for waters of the XJF.

The $\mathrm{EF}_{\mathrm{i}}$ of $\mathrm{B}, \mathrm{Sb}, \mathrm{Li}, \mathrm{Sr}$, and $\mathrm{Mo}$ are relatively higher than others (Figure 5). The mobile chalcophile elements may originate from external sources such as sulfide-enriched altered rocks. Contribution from magmatic vapors cannot be excluded either, especially for boron. The contents of alkali metal elements such as $\mathrm{Li}$ are generally lower than major elements, but due to their active chemical properties, strong oxytropism, mainly enriched in acidic rocks, and strong migration ability, the contents of some springs are close to or even exceed the abundance of surrounding rocks. Alkali earth metals $\mathrm{Sr}$ and Ba are disperse elements with high abundance in crust and mantle, and their migration is closely related to $\mathrm{Ca}$. $\mathrm{Sr}$ was more easily enriched into weak alkaline water with $\mathrm{pH}$ of 7.0 8.5 [58]. Due to the carbonate and clastic developed around the $\mathrm{XJF}$, the $\mathrm{pH}$ value of spring samples ranged from 6.49 to 7.66, with a mean value of 7.21, which was beneficial to enriching $\mathrm{Sr}$ in the study area. $\mathrm{Sb}$ and Mo have strong migration ability in an alkaline reduction environment, and $\mathrm{Sb}$ and Mo may be more affected by surrounding rock minerals. As a variable valence element, Fe is affected by precipitators, acidity and alkalinity of solution, and oxidation reducibility. Meanwhile, high concentration areas of $\mathrm{Fe}^{2+}$ are mainly distributed in Xundian (S7) and Yiliang (S8) hot springs, in which Neogene thin-layer argillaceous dolomite and lignite were developed. The high concentration of $\mathrm{Fe}^{2+}$ is mainly attributed to the pyrite dissolution of the lignite of surrounding rocks in hot springs. In addition, previous studies illustrated that when both the depth and pressure increased, the solubility of $\mathrm{B}^{2+}$ in the groundwater increased [41,58]. High concentration areas of $\mathrm{B}^{2+}$ are mainly distributed in the middle eastern branch segment of the XJF, i.e., the Dazhaicangfang hot spring (S6), Xundiantangzi hot spring (S7), Qujiang hot spring (S9), and Longxicun hot spring (S22), indicating that the circulation depth of hot springs in this segment is larger. The content of these elements in groundwater of the study area may be related to the higher geochemical background values of them.

\subsection{Water-Rock Interaction of Hot Springs When Circulating inside the Fault \\ 5.3.1. The Water-Rock Reaction Equilibrium}

Chemical equilibration was tested with a ternary diagram established using relative $\mathrm{Na} / 1000, \mathrm{~K} / 100$, and $\mathrm{Mg}^{1 / 2}$ contents [59]. The Na-K-Mg triangular plot (Figure 6) shows that S9 and S24 water samples plot in the partial equilibration zone, whereas other hot spring samples plot in the immature water zone. The water chemical types were classified on the basis of major ions and the Piper diagram (Figure 3). $\mathrm{HCO}_{3}-\mathrm{Na}$ is the dominant water chemical type for the S9 and S24 hot spring, located at the junction of the southern segment of the XJF and the Jianshui fault (Figure 1b). 


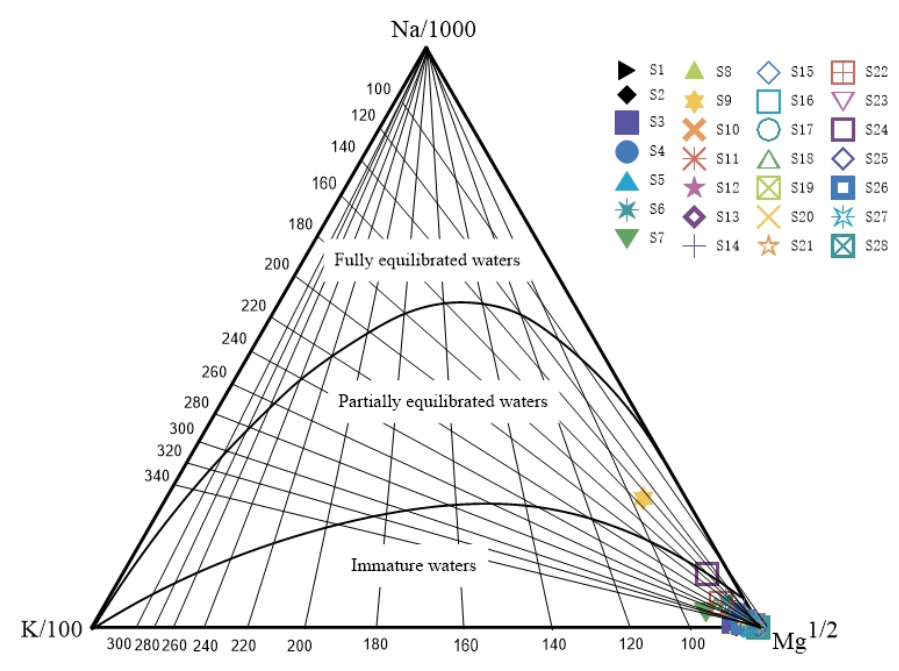

Figure 6. Distribution of aqueous samples on the $\mathrm{Na} / 1000-\mathrm{K} / 100-\mathrm{Mg}^{1 / 2}$ ternary diagram.

\subsubsection{Reservoir Temperature and Circulation Depth}

The chemical geothermometers including the quartz, the chalcedony, and the cation geothermometers, including the $\mathrm{Na}-\mathrm{K}, \mathrm{K}-\mathrm{Mg}, \mathrm{Ca}-\mathrm{Mg}$, Na-K-Ca, Na-K-CaMg-corrected, and the Na-Li systems are commonly used to estimate reservoir temperature [59-67]. The different chemical geothermometers always yield very different reservoir temperatures owing to the complex geological settings. Most of the hot spring water samples did not reach water-rock equilibrium in this study, indicating that the cation geothermometers were not suitable to estimate the reservoir temperature [64-67]. Additionally, the water temperature was not high, with basically no steam loss or some spring point steam loss that was very small. In this study, we used the quartz geothermometers with no steam loss, the chalcedony $[63,68]$. The data of reservoir temperature were evaluated according to Equation (2):

$$
\mathrm{T}=1309 /\left(5.91-\log \left(\mathrm{C}_{\mathrm{SiO} 2}\right)\right)-273.15
$$

$\mathrm{C}_{\mathrm{SiO} 2}$ indicates the concentration of $\mathrm{SiO}_{2}$ in the water [66] and the results are shown below (Table 1). Therefore, the reservoir temperature of spring samples in the XJF is mainly $24.3^{\circ} \mathrm{C} \sim 96.0^{\circ} \mathrm{C}$.

The data of circulation depth were evaluated according to Equation (3):

$$
Z=Z_{0}+\left(T-T_{0}\right) / T_{\text {grad }}
$$

$Z$ is the circulation depth $(\mathrm{km}) ; Z_{0}$ is the depth of constant temperature zone $(\mathrm{km}) ; T$ is the reservoir temperature $\left({ }^{\circ} \mathrm{C}\right) ; T_{0}$ is the temperature of constant temperature zone $\left({ }^{\circ} \mathrm{C}\right)$, namely the local average temperature; $T_{\text {grad }}$ is the geothermal gradient $\left({ }^{\circ} \mathrm{C} / \mathrm{km}\right)$ reflecting the geothermal change per one kilometer of the place below the constant temperature zone [69]. By taking reference from previous studies on the groundwater in some areas of Yunnan Province, the geothermal gradient $T_{\text {grad }}$ was assumed as $20^{\circ} \mathrm{C} / \mathrm{km}$, the annual mean temperature $\mathrm{T}_{0}$ assumed as $15.8^{\circ} \mathrm{C}$, and the depth $Z_{0}$ of the constant temperature zone assumed as $30 \mathrm{~m}$. The final circulation depth of the XJF is about $0.45 \sim 4.04 \mathrm{~km}$ as calculated. The reservoir temperature of hot springs is positively associated with the circulation depth. The deeper the circulation of a spring is, possibly the longer the circulation path is, and the greater the opportunity and proportion of cold-water mixture will be, indicating a great temperature difference between the spring vent and the reservoir. The southern segment of the XJF showed the greatest circulation depth of hot spring water $(4.04 \mathrm{~km})$ and a temperature difference of $34.2^{\circ} \mathrm{C}$, followed by Shuanghexiang area located in the northern segment (circulation depth: 0.96 2.33 km; temperature difference: $0.6 \sim 15.1^{\circ} \mathrm{C}$ ) (Table 1). In the middle segment of the fault, obvious differences of circulation depth could be suggested in the east branch, with circulation depth of $0.45 \sim 3.45 \mathrm{~km}$ and 
temperature difference of $0.7 \sim 25.8^{\circ} \mathrm{C}$, and the overall mean values were greater than those of the west branch where the circulation depth was $1.46 \sim 1.86 \mathrm{~km}$ and the temperature difference was $13.2 \sim 15.5^{\circ} \mathrm{C}$.

Table 1. Analytical data of reservoir temperature and circulation depth.

\begin{tabular}{|c|c|c|c|c|c|c|}
\hline NO. & $\begin{array}{c}\text { Temperature } \\
\left({ }^{\circ} \mathrm{C}\right)\end{array}$ & $\mathrm{SiO}_{2}(\mathrm{mg} / \mathrm{L})$ & $\begin{array}{c}\text { Reservoir } \\
\text { Temperature }\left({ }^{\circ} \mathrm{C}\right)\end{array}$ & $\begin{array}{l}\text { Circulation } \\
\text { Depth (km) }\end{array}$ & $\begin{array}{c}\text { Temperature Difference } \\
\text { between Spring Vent } \\
\text { and Reservoir }\left({ }^{\circ} \mathrm{C}\right)\end{array}$ & Structural Location \\
\hline S11 & 46.6 & 19.10 & 61.7 & 2.33 & 15.1 & \multirow{3}{*}{ Northern Segment } \\
\hline S1 & 43.0 & 16.80 & 57.0 & 2.09 & 14.0 & \\
\hline $\mathrm{S} 2$ & 33.7 & 8.56 & 34.3 & 0.96 & 0.6 & \\
\hline S12 & 40.8 & 12.10 & 45.6 & 1.52 & 4.8 & \multirow{6}{*}{$\begin{array}{l}\text { Middle eastern } \\
\text { branch Segment }\end{array}$} \\
\hline S3 & 37.0 & 14.70 & 52.3 & 1.85 & 15.3 & \\
\hline S4 & 40.1 & 15.20 & 53.4 & 1.91 & 13.3 & \\
\hline S6 & 45.2 & 13.50 & 49.3 & 1.70 & 4.1 & \\
\hline S10 & 23.6 & 6.15 & 24.3 & 0.45 & 0.7 & \\
\hline S7 & 58.5 & 33.70 & 84.3 & 3.45 & 25.8 & \\
\hline S13 & 37.0 & 14.80 & 52.5 & 1.86 & 15.5 & \multirow{2}{*}{$\begin{array}{l}\text { Middle western } \\
\text { branch Segment }\end{array}$} \\
\hline S14 & 31.2 & 11.70 & 44.4 & 1.46 & 13.2 & \\
\hline S20 & 53.2 & 19.80 & 63.1 & 2.39 & 9.9 & \multirow{5}{*}{ Southern Segment } \\
\hline S18 & 48.2 & 22.40 & 67.8 & 2.63 & 19.6 & \\
\hline S16 & 30.1 & 8.65 & 34.6 & 0.97 & 4.5 & \\
\hline S15 & 40.0 & 16.50 & 56.4 & 2.06 & 16.4 & \\
\hline S9 & 61.8 & 44.10 & 96.0 & 4.04 & 34.2 & \\
\hline
\end{tabular}

\subsubsection{Mineral Saturation States}

Mineral equilibrium calculations could be used to estimate the mineral reactivity in hot spring waters by the parameter of saturation index (SI) without examining samples of the solid phases [70]. It is possible to predict which minerals may precipitate during the extraction and the use of thermal fluids. Mineral saturation indices of hydrothermal minerals that are likely to be present in the reservoir of geothermal system were calculated at the outlet temperature and $\mathrm{pH}$ by PHREEQC software. Results are presented in Figure 7. Nearly all groundwater samples are supersaturated (SI $>0)$ with respect to calcite at sampling temperatures suggesting that $\mathrm{CO}_{2}$ degassing may have occurred (Figure 7). Only samples $8,23,24,27$, and 28 have negative values, but they are also nearly in equilibrium with calcite. Scaling of the carbonate minerals with the exception of samples $8,23,24$, 27 , and 28 is expected for thermal waters. This supersaturation state demonstrates the presence of substantial amounts of these minerals and sufficient residence time in the aquifer system [71]. Groundwater samples S7, S12, S18, and S22 are in equilibrium with gypsum and anhydrite (SI 0). Almost all groundwater samples are in under saturation with halite $(\mathrm{SI}<-6)$.

\subsection{Correlation between Hydrogeochemical Changes and Earthquakes}

\subsubsection{Precursory and Postseismic Anomalies}

Groundwater anomalies have been among the earliest and most frequently reported phenomena to occur in conjunction with earthquake activity. Previous studies suggested the occurrence of an earthquake brings energy and a series of hydrological changes consequently, which is closely associated with earthquake magnitude and distance [72]. A continuous measure was preformed every three days in the Xundian hot spring (S7) since April 2019, and in Panxi (S16) and Qujiang (S9) hot springs since June 2019. In our study area, $M>4$ earthquakes occurred on three occasions: Xundian $M_{\mathrm{L}} 4.2$ earthquake on January 15 , 2020, Dongchuan $M_{\mathrm{L}} 4.2$ earthquake on 8 July 2020, and Shuangbai $M_{\mathrm{L}} 5.1$ earthquake on 10 June 2021 (Figure 1). The first two earthquakes were caused by strike-slip fault motion within the XJF, while the last earthquake was caused by strike-slip fault motion within the SP-JSF. 


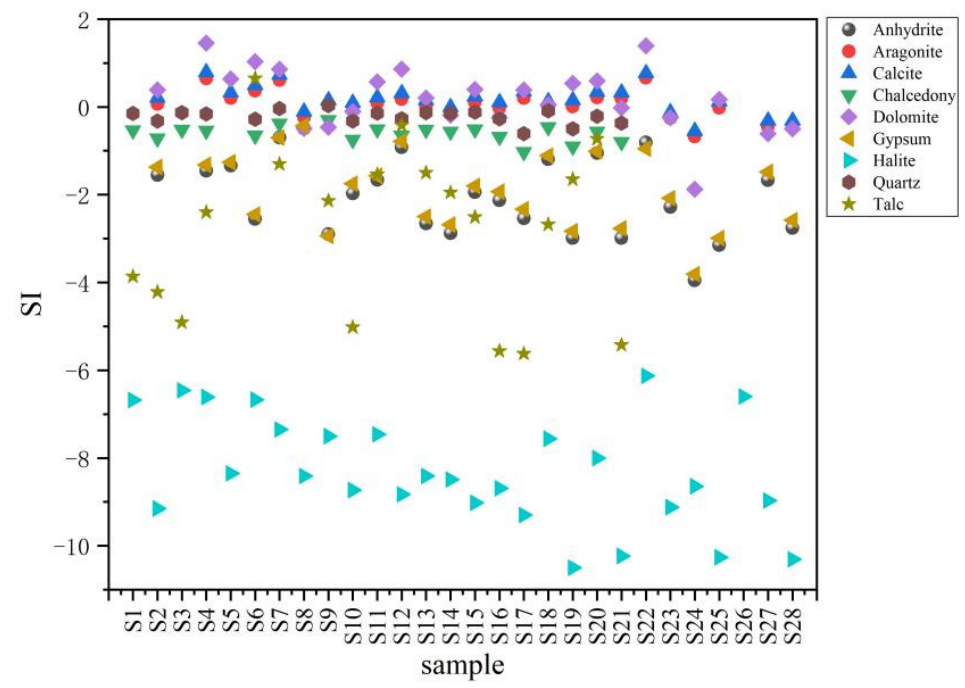

Figure 7. Saturation indices values of groundwater samples with respect to minerals.

Hydrochemical data of the water samples showed an evident trend of temporal variation. The $\mathrm{Na}^{+}, \mathrm{Cl}^{-}$, and $\mathrm{SO}_{4}{ }^{2-}$ are also sensitive to area stress and are usually observed in international seismic event monitoring $[24,29,73]$. We observed that there were some irregular fluctuations in the major ions $\left(\mathrm{Na}^{+}, \mathrm{Cl}^{-}\right.$, and $\left.\mathrm{SO}_{4}{ }^{2-}\right)$ and TDS before and after the earthquake. Change point (CP) detection in the time-series data of the major ions $\left(\mathrm{Na}^{+}\right.$, $\mathrm{Cl}^{-}$, and $\mathrm{SO}_{4}{ }^{2-}$ ) and TDS in three sites reveals that each cluster has at least one $\mathrm{CP}$ within a central period, which is characterized by seismic events (Figure 8 and Table S5) [47]. There was no obvious association between the hydrochemical composition anomaly and the precipitation during the three earthquake events (Figure 8). The variation trend of $\mathrm{Cl}^{-}$concentration seems in good agreement with near-field seismic activity within $50 \mathrm{~km}$ and with a magnitude range from $M_{\mathrm{L}} 1.0$ to $M_{\mathrm{L}}$ 4.0. In most near-field seismic activities, the hydrochemical composition variations show a lack of obvious association or a low fluctuation (Figure 8), so it is inferred that the response zone of near-field seismic activity is local and limited. The groundwater changes triggered by the far-field earthquakes within $300 \mathrm{~km}$ and with a magnitude range over $M_{\mathrm{L}} 4.0$ are considered to be regional rather than local.

The occurrence time of anomalies and epicentral distance of three earthquakes in the three hot springs are shown in Table 2. Prior to the Shuangbai $M_{\mathrm{L}} 5.1$ earthquake on 10 June 2021, obvious precursory anomalies of $\mathrm{Na}^{+}, \mathrm{Cl}^{-}, \mathrm{SO}_{4}{ }^{2-}$, and TDS concentrations appeared in the S7 (Xundian), S9 (Qujiang), and S16 (Panxi) sites, located 179.3, 100.4, and $120.2 \mathrm{~km}$ away from the epicenter, respectively (Figure 8), and then it was found that the concentrations of $\mathrm{Na}^{+}, \mathrm{Cl}^{-}$, and $\mathrm{SO}_{4}{ }^{2-}$ all stayed at a relatively high level after the Shuangbai $M_{\mathrm{L}} 5.1$ earthquake. These compositional modifications can be explained by permanent changes in the aquifers that are caused by tectonic events. Meanwhile, for the same earthquake (Shuangbai $M_{\mathrm{L}} 5.1$ ) or the same site (S7), it is observed that the closer the epicentral distance is, the earlier the anomalies appeared (Table 2). For the site with the same epicentral distance, the larger the magnitude is, the earlier the anomalies appeared. For example, in S16 hot spring, the concentrations of $\mathrm{Cl}^{-}, \mathrm{SO}_{4}{ }^{2-}$, and TDS started to exceed the abnormal threshold value in 24 days prior to the Shuangbai $M_{\mathrm{L}} 5.1$ earthquake, earlier than the Xundian $M_{\mathrm{L}} 4.2$ and Dongchuan $M_{\mathrm{L}} 4.2$ earthquakes. 


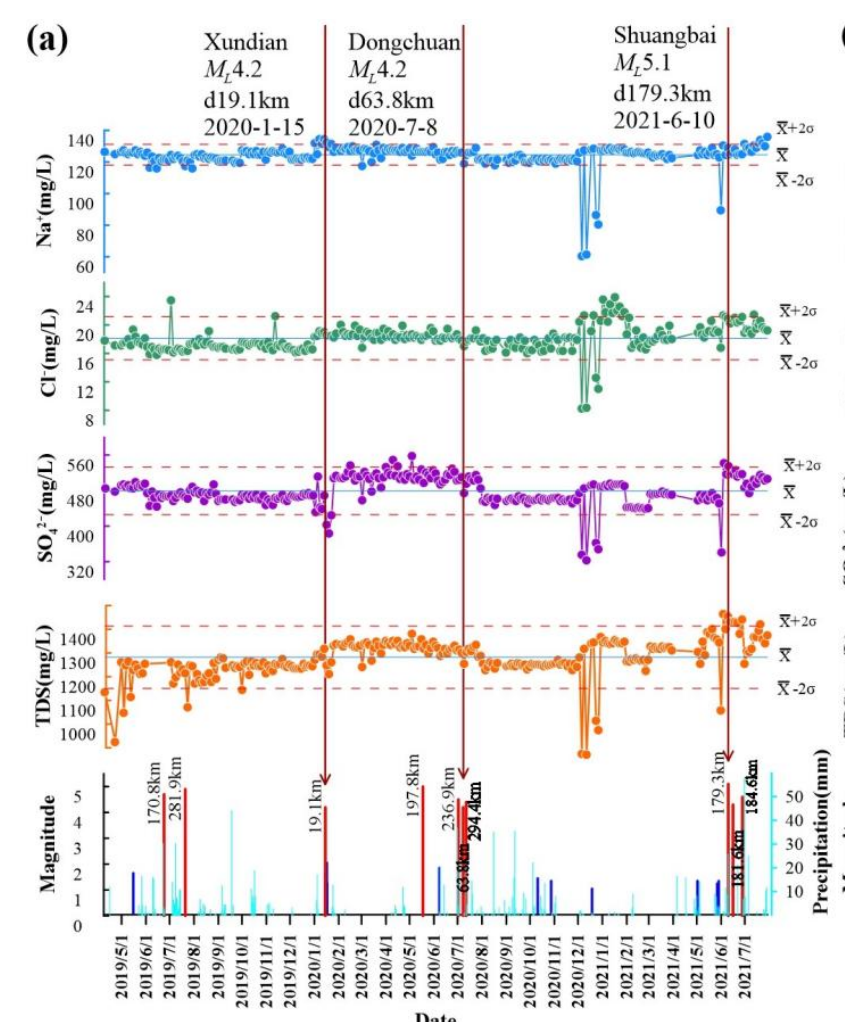

Date

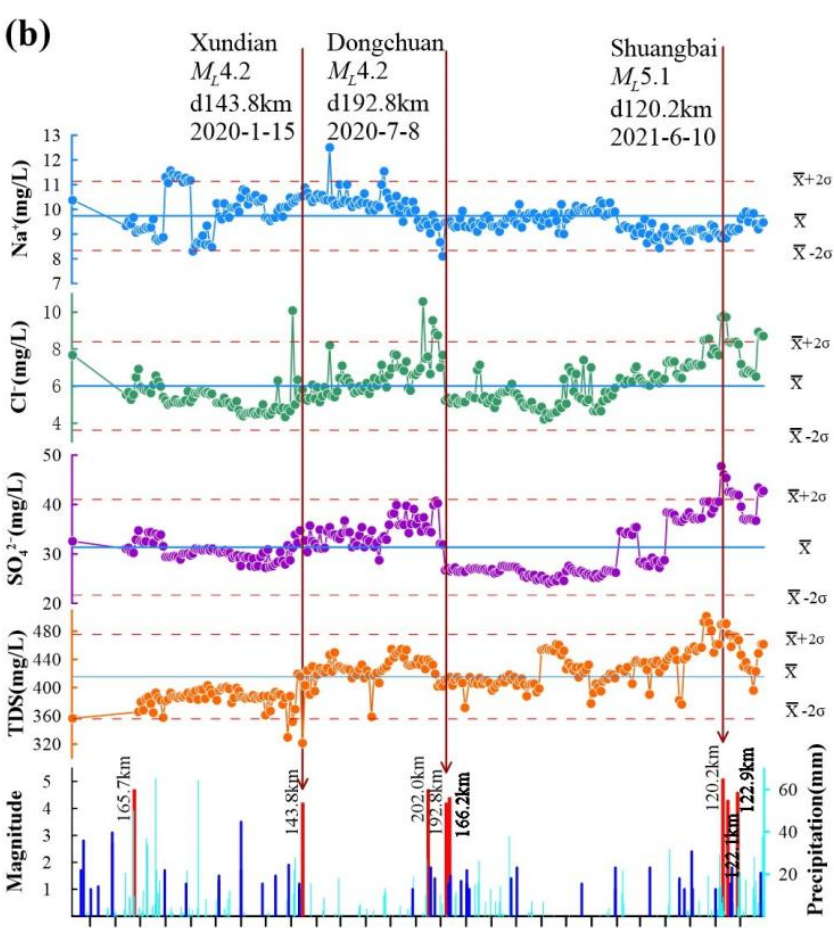

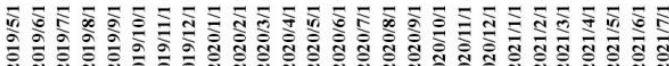

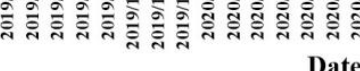

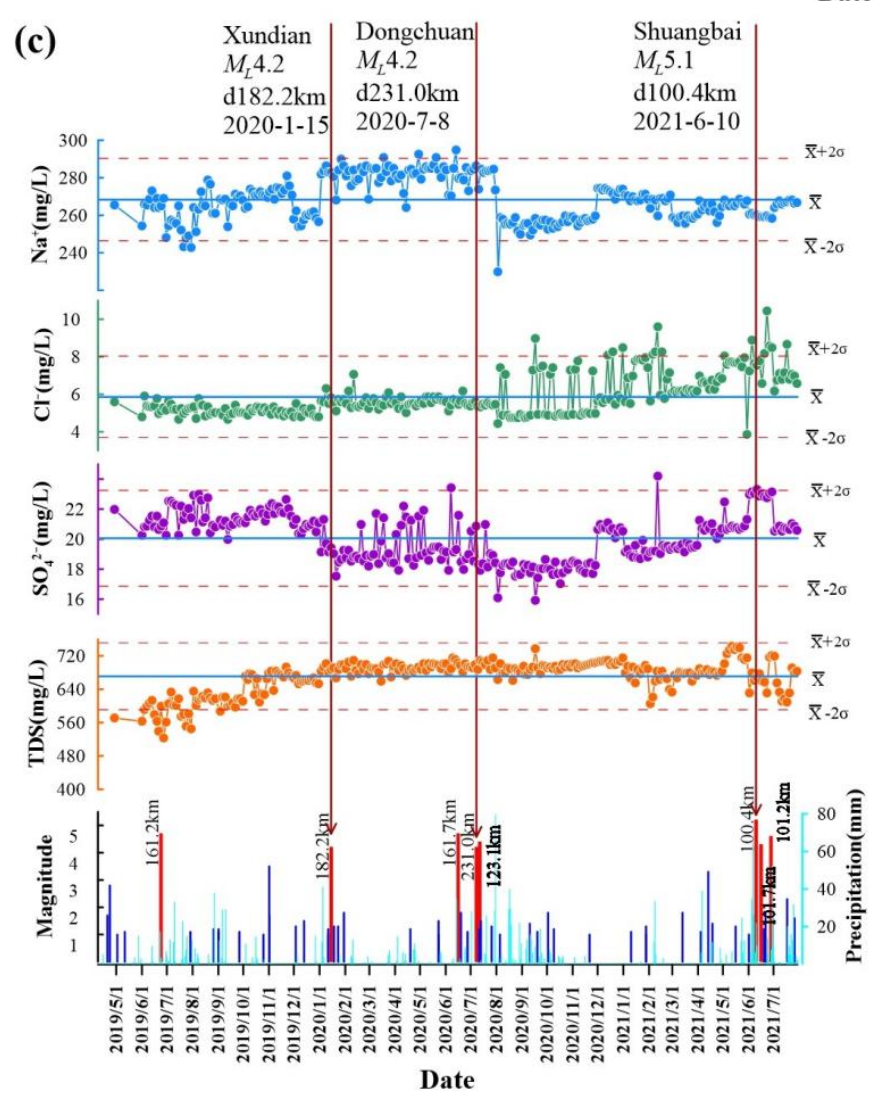

Figure 8. Temporal variations of concentration of $\mathrm{Na}^{+}, \mathrm{Cl}^{-}, \mathrm{SO}_{4}{ }^{2-}$, TDS, precipitation, and earthquake: (a) is the Xundian spring (S7); (b) is the Panxi spring (S16); and (c) is the Qujiang hot spring (S9). Blue bars show the near-field earthquakes within $50 \mathrm{~km}$ and magnitude range from $M_{L} 1.0$ to $M_{L} 4.0$. Red bars show the far-field earthquakes within $300 \mathrm{~km}$ and magnitude range over $M_{L}$ 4.0. The precipitation means daily mean value. 
Table 2. Analytical data of reservoir temperature and circulation depth.

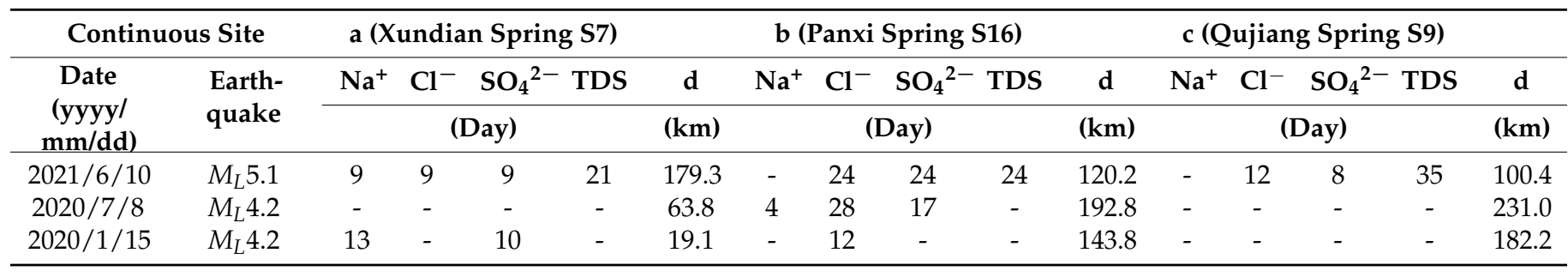

'-' represents not over anomaly threshold.

Statistical analyses indicated that the changes in groundwater chemistry were associated with the earthquakes $[47,74]$. Several investigators have proposed that microfracturing in the basement rock due to seismic stress prior to major seismic events is responsible for precursory changes in hydrochemistry and other related parameters [75]. During the micro-fracturing development, the crustal strain dilation or aquifer permeability changes caused mixtures of different water $[14,16,76,77]$, then the concentration of hydrochemistry changed, until the earthquake, and the tectonic movement occurred with the catastrophe. The concentration of $\mathrm{Cl}^{-}$in a nearby spring increased by $36.0 \%$ above background values 5 days prior to the 1996 Pyrenees $M_{L} 5.2$ earthquake in France. Toutain et al. [73] suggested that this precursory chemical change was attributed to a preseismic strain change, which induced mixing of geochemically different aquifers. The mechanism of fluid mixing is believed to be due to precursory fracturing of hydrologic barriers that separate the individual aquifer system $[1,78,79]$. The source mixing resulted in a shift from equilibrium and triggered water-rock interaction. As shown in Figure 8a, the TDS values were agreed with the tendency of changes in the contents of $\mathrm{Na}^{+}, \mathrm{Cl}^{-}$, and $\mathrm{SO}_{4}{ }^{2-}$, which also validated the impact of seismic activity on the water-rock reaction equilibrium. The three hot springs were in equilibrium with gypsum, anhydrite, quartz, chalcedony, and calcite, and the surrounding rock included limestone, dolomites, sandstones, and shales that are coal-bearing (Table S1 and Figure 7). Therefore, there is a capacity for increasing sulphate, sodium, and calcium ions along the flow paths [71,80].

Nevertheless, changes of hydrochemical compositions were not observed in Qujiang hot spring (S9), which was located $182 \mathrm{~km}$ away from the epicenter of Xundian $M_{\mathrm{L}} 4.2$ earthquake and $231 \mathrm{~km}$ away from the epicenter of Dongchuan $M_{\mathrm{L}} 4.2$ earthquake (Figure 8c). Considering the structural position and distance from earthquake events, it can be inferred that the seismic response zone of hot spring monitoring stations is not only closely associated with earthquake magnitude and distance, but also controlled by tectonic stress in deep and large faults. The S7 and S16 are mainly controlled by the XJF, while the S9 is located in the structure intersection among the XJF, QJF, and SP-JSF (Figure 1b), which are conjugated strike-slip faults. This suggests the potential relationship between hydrochemical composition anomaly and regional stress field, which influences the fault permeability in terms of strain partitioning across active faults. Precursory anomalies for the Shuangbai $M_{\mathrm{L}} 5.1$ earthquake in the spring S9 confirmed the anisotropic character of the stress/strain transmission through the tectonic discontinuities between the focal zone and the measurement site [35].

The three hot springs considered herein are located in a deep and large active fault zone (XSHF and XJF) and are sensitive to seismicity. The XSHF and XJF strain field is a huge left-lateral strike-slip active fault system. The maximum shear strain rate of 40-60 nanostrain/yr is found along the XSHF-XJF system, which delineates the north and east boundaries of the crustal materials undergoing large-scale clockwise rotation around the eastern Himalaya syntaxis [81]. When the stress increased up to the subinstability stress state of the faults in the XSHF-XJF system, earthquakes occurred [82]. The concentrations of $\mathrm{Na}^{+}, \mathrm{Cl}^{-}$, and $\mathrm{SO}_{4}{ }^{2-}$ are sensitive to the increase of stress in the XSHF-XJF system, which could enhance the opening of micro-fractures under the three hot springs. According to the variation characteristics of stress and strain, the anomalies of $\mathrm{Na}^{+}$, $\mathrm{Cl}^{-}$, and $\mathrm{SO}_{4}{ }^{2-}$ concentration have different characteristics. It exhibits a persistent stress 
increase most probably caused by a persistent contribution of the different depths caused by the strain release before the seismic events [83,84]. A similar observation was reported by Zhou et al. [85] in Luojishan hot spring bubbling gas, where obvious short-term seismic precursor anomalies of $\mathrm{H}_{2}$ concentration were discovered before some earthquakes.

\subsubsection{The Hydrogeochemical Circulation Model of Hot Spring Waters in Xiaojiang Fault}

An understanding of the origin and migration pathways of groundwater in an active seismic area is of paramount importance in terms of studying hydrogeochemical precursors in a seismic hazards zone [86]. A conceptual model for the origin of groundwater and the hydrogeochemical cycling process in the XJF is summarized in Figure 9 according to the previous geophysical data and the results of this study.

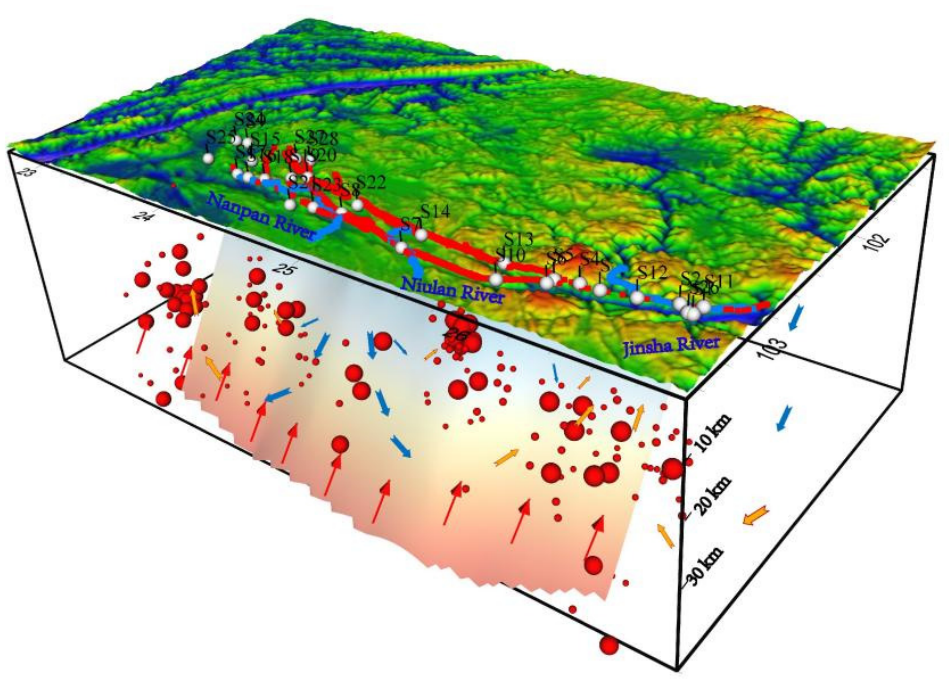

Figure 9. Conceptual model of the origin of groundwater and the hydrogeochemical cycling process in the XJF.

In the recharge area at an altitude of $1.8-4.5 \mathrm{~km}$, meteoric waters permeated into aquifers along the fractures between and around mountains and river terraces through the waterconducting fault zone. Previous studies have revealed that a pronounced high electric conductivity and low-velocity materials were observed from the Songpan-Ganzi block to the southern Sichuan-Yunnan diamond block [87]. The fault zone subvertical conductors of the XJF were interpreted to represent fault damage zones that formed by strike-slip faulting/shearing along the faults and filled with deeply sourced magmatic and/or metamorphic fluids. The lower crust is broadly characterized by enhanced conductivity and likely associated with partial melting at high temperatures [18,72,88,89]. Additionally, the XJF is characterized by moderately high total strain rates and low ${ }^{3} \mathrm{He} /{ }^{4} \mathrm{He}$ values (mostly $<0.10 \mathrm{RA}$ ), suggesting that crustal He degassing dominates such fault regions [35]. Thus, we inferred that the XJF acted as a tunnel of these groundwaters in the crust which could be heated by hot material in this region. When the circulation depth of groundwater was increased to $0.45-4.04 \mathrm{~km}$, and the water was heated to $24.3-96.0^{\circ} \mathrm{C}$, water-rock reactions would occur with surrounding rocks at different depths (i.e., granite, igneous rock, etc.) under certain temperature-pressure conditions. Due to different extents of reactions, partially equilibrated water and immature water were produced, then they could be mixed with the cold surface water or shallow groundwater when ascending to the surface ground, and finally becoming exposed on the earth's surface as a hot spring. If the crustal stress in the area changes, the equilibrated state of hot spring water will be broken and the hydrochemical information carried by such waters will change [78]. Therefore, continuous monitoring could be conducted on a proper hot spring spot of the fault zone to further study the pre-seismic hydrochemical precursors. The results of this study indicate that faults play a crucial role in controlling the migration of crustal fluids. In addition, they reveal that possible evaluation of potential seismic precursors mandatorily requires a long period of sustainability monitoring. 


\section{Conclusions}

The detailed mechanism and process of geochemical changes in the XJF were described in terms of regional groundwater flow systems by using a large amount of hydrochemical data from 28 hot spring sites. Our results suggested that hot spring water in the XJF was mainly recharged by atmospheric precipitation from nearby mountains, and the recharged elevations ranged from 1.8 to $4.5 \mathrm{~km}$. Hydrochemical types were mainly controlled by aquifer lithology, in which, sodium bicarbonate water gathered mainly in the southern part of the fault zone, while calcium magnesium sulfites gathered in the northern part, and calcium magnesium water in most other areas. The temperature range was inferred from an equation based on the $\mathrm{SiO}_{2}$ concentration and chemical geothermal modeling: $24.3 \sim 96.0^{\circ} \mathrm{C}$. The circulation depths for the springs were estimated to be from 0.45 to $4.04 \mathrm{~km}$.

Meanwhile, our results presented a good correlation between hydrochemical composition anomalies and earthquakes according to the regional stress field. In Xundian, Panxi, and Qujiang springs, there were short-term (4-35 d) seismic precursor anomalies of the hydrochemical compositions prior to the Xundian $M_{\mathrm{L}} 4.2$ earthquake, Dongchuan $M_{\mathrm{L}} 4.2$ earthquake, and Shuangbai $M_{\mathrm{L}} 5.1$ earthquake. The epicentral distance of anomalous sites ranged from 19.1 to $192.8 \mathrm{~km}$. The anomalous amplitude were all over 2 times the anomaly threshold. The seismic precursory anomalies indicated that synchronous hydrogeochemical anomalies and duration of the springs controlled by the same tectonic stress were not only closely associated with earthquake magnitude and distance but were also controlled by tectonic stress in deep and large faults.

In conclusion, we speculated that the meteoric water firstly infiltrated underground and was heated by heat sources, and later circulated to the earth's surface along the fault and fracture and finally constituted hot spring recharge. The results also provided useful information about the earthquake-related response mechanisms occurring in the $\mathrm{XJF}$, which represent the basic task for planning and managing the impending hydrogeochemical network aimed at defining the relationships between seismic cycle, fluids, and reliable earthquake precursors. Of course, further studies are required to confirm the main conclusions arrived at in the present study.

Supplementary Materials: The following are available online at https:/ /www.mdpi.com/article/ 10.3390/w13192638/s1, Table S1: Location of the surveyed area of hot spring in the XJF, Table S2: Field and analytical data of major elements on water samples. Chemical types are based on a Piper diagram, Table S3: Analytical data of trace elements on hot spring water sample, Table S4: Values of stable isotopes $\delta \mathrm{D}, \delta 18 \mathrm{O}$ and recharge elevation of hot spring, Table S5: Results of the three continuous monitoring sites.

Author Contributions: Conceptualization, C.L. and X.Z.; methodology, C.L., X.Z., and Y.Y.; software, C.L.; validation, S.O. and F.L.; formal analysis, C.L.; investigation, C.L., X.Z., S.O., and F.L.; data curation, C.L. and X.Z.; writing — original draft preparation, C.L.; writing — review and editing, C.L. and X.Z.; visualization, C.L.; supervision, X.Z. All authors have read and agreed to the published version of the manuscript.

Funding: This research was funded by National Key Research and Development Project (grant number: 2017YFC1500501-05, 2019YFC1509203), the National Natural Science Foundation of China (grant number: 41673106, 42073063, 4193000170), The Special Fund of the Institute of Earthquake Forecasting, China Earthquake Administration (grant number: 2018IEF010104, 2020IEF0604, 2020IEF0703, 2021IEF0602, 2021IEF0101, 2021IESLZ05), and the Science and Technology Program of Gansu Province, China (grant number: 20JR10RA500).

Data Availability Statement: The raw data supporting the conclusions of this article will be made available by the authors, without undue reservation.

Acknowledgments: The authors are grateful to the Editor, Simone Zhang, and anonymous reviewers for their constructive comments and suggestions.

Conflicts of Interest: The authors declare no conflict of interest. 


\section{References}

1. Skelton, A.; Andrén, M.; Kristmannsdóttir, H.; Stockmann, G.; Mörth, C.M.; Sveinbjörnsdóttir, Á.; Jónsson, S.; Sturkell, E.; Guõrúnardóttir, H.R.; Hjartarson, H.; et al. Changes in groundwater chemistry before two consecutive earthquakes in Iceland. Nat. Geosci. 2014, 7, 752-756. [CrossRef]

2. Shi, Z.; Shi, Z.; Yin, G.; Liang, J. Travertine deposits, deep thermal metamorphism and tectonic activity in the Longmenshan tectonic region, southwestern China. Tectonophysics 2014, 633, 156-163. [CrossRef]

3. Griffin, S.; Horton, T.W.; Oze, C. Origin of warm springs in Banks Peninsula, New Zealand. Appl. Geochem. 2017, 86, 1-12. [CrossRef]

4. He, A.; Singh, R.P. Coseismic Groundwater Temperature Response Associated with the Wenchuan Earthquake. Pure Appl. Geophys. 2019, 177, 109-120. [CrossRef]

5. Hosono, T.; Masaki, Y. Post-seismic hydrochemical changes in regional groundwater flow systems in response to the $2016 \mathrm{Mw} 7.0$ Kumamoto earthquake. J. Hydrol. 2020, 582, 124340. [CrossRef]

6. Hosono, T.; Yamada, C.; Shibata, T.; Tawara, Y.; Wang, C.Y.; Manga, M.; Rahman, A.T.M.S.; Shimada, J. Coseismic groundwater drawdown along crustal ruptures during the 2016 Mw 7.0 Kumamoto earthquake. Water Resour. Res. 2019, 55, 5891-5903. [CrossRef]

7. Nakagawa, K.; Yu, Z.Q.; Berndtsson, R.; Hosono, T. Temporal characteristics of groundwater chemistry affected by the 2016 Kumamoto earthquake using self-organizing maps. J. Hydrol. 2020, 582, 124519. [CrossRef]

8. Shi, Z.; Zhang, H.; Wang, G. Groundwater trace elements change induced by M5.0 earthquake in Yunnan. J. Hydrol. 2020, 581, 124424. [CrossRef]

9. Sano, Y.; Takahata, N.; Igarashi, G.; Koizumi, N.; Sturchio, N.C. Helium degassing related to the Kobe earthquake. Chem. Geol. 1998, 150, 171-179. [CrossRef]

10. Aydın, H.; Hilton, D.R.; Güleç, N.; Mutlud, H. Post-earthquake anomalies in He-CO2, isotope and relative abundance systematics of thermal waters: The case of the 2011 Van earthquake, eastern Anatolia, Turkey. Chem. Geol. 2015, 411, 1-11. [CrossRef]

11. King, C.-Y.; Koizumi, N.; Kitagawa, Y. Hydrogeochemical Anomalies and the 1995 Kobe Earthquake. Science 1995, 269, 38-39. [CrossRef] [PubMed]

12. Du, J.; Cheng, W.; Zhang, Y.; Jie, C.; Guan, Z.; Liu, W.; Bai, L. Helium and carbon isotopic compositions of thermal springs in the earthquake zone of Sichuan, Southwestern China. J. Asian Earth Sci. 2006, 26, 533-539. [CrossRef]

13. Wen, X.; Du, F.; Long, F.; Zhu, H. Tectonic dynamics and correlation of major earthquake sequences of the Xiaojiang and Qujiang-Shiping fault systems, Yunnan, China. Sci. China Earth Sci. 2011, 54, 1563-1575. [CrossRef]

14. Liu, L.; Du, J.; Zhou, X.; Li, Y.; Xie, C.; Cui, Y. Continuously observation of fault fluid geiochemistry after Yushu Ms7.1 earthquake. Prog. Geophys. 2012, 27, 888-893. (In Chinese)

15. Ingebritsen, S.E.; Manga, M. Hydrogeochemical precursors. Nat. Geosci. 2014, 7, 697-698. [CrossRef]

16. Zhou, X.; Liu, L.; Chen, Z.; Cui, Y.; Du, J. Gas geochemistry of the hot spring in the Litang fault zone, Southeast Tibetan Plateau. Appl. Geochem. 2017, 79, 17-26. [CrossRef]

17. Zhang, M.; Tang, Q.; Cao, C.; Li, W.Y.; Wang, H.; Li, Z.P. The origin of Permian Pobei ultramafic complex in the northeastern Tarim craton, western China: Evidences from chemical and C-He-Ne-Ar isotopic compositions of volatiles. Chem. Geol. 2017, 469, 85-96. [CrossRef]

18. Li, X.; Bai, D.; Ma, X.; Chen, Y.; Varentsov Ivan, M.; Xue, G.; Xue, S.; Lozovsky, I. Electrical resistivity structure of the Xiaojiang strike-slip fault system (SW China) and its tectonic implications. J. Asian Earth Sci. 2019, 176, 57-67. [CrossRef]

19. Barbieri, M.; Boschetti, T.; Barberio, M.D.; Billi, A.; Franchini, S.; Iacumin, P.; Selmo, E.; Petitta, M. Tracing deep fluid source contribution to groundwater in an active seismic area (central Italy): A combined geothermometric and isotopic $\left(\delta^{13} \mathrm{C}\right)$ perspective. J. Hydrol. 2020, 582, 124495. [CrossRef]

20. Barberio, M.D.; Gori, F.; Barbieri, M.; Billi, A.; Caracausi, A.; De Luca, G.; Franchini, S.; Petitta, M.; Doglioni, C. New observations in Central Italy of groundwater responses to the worldwide seismicity. Sci. Rep. 2020, 10, 17850. [CrossRef]

21. Buttitta, D.; Caracausi, A.; Chiaraluce, L.; Favara, R.; Sulli, A. Continental degassing of helium in an active tectonic setting (northern Italy): The role of seismicity. Sci. Rep. 2020, 10, 162. [CrossRef]

22. Martinelli, G.; Facca, G.; Genzano, N.; Gherardi, F.; Lisi, M.; Pierotti, L.; Tramutoli, V. Earthquake-related signals in central Italy detected by hydrogeochemical and satellite techniques. Front. Earth Sci. 2020, 8, 584716. [CrossRef]

23. Martinelli, G.; Ciolini, R.; Facca, G.; Fazio, F.; Gherardi, F.; Heinicke, J.; Pierotti, L. Tectonic-Related Geochemical and Hydrological Anomalies in Italy during the Last Fifty Years. Minerals 2021, 11, 107. [CrossRef]

24. Andrén, M.; Stockmann, G.; Skelton, A.; Sturkell, E.; Mörth, C.M.; Guðrúnardóttir, H.R.; Keller, N.S.; Odling, N.; Dahrén, B.; Broman, C.; et al. Coupling between mineral reactions, chemical changes in groundwater, and earthquakes in Iceland. J. Geophys. Res. Solid Earth 2016, 121, 2315-2337. [CrossRef]

25. Coppola, M.; Correale, A.; Barberio, M.D.; Billi, A.; Cavallo, A.; Fondriest, M.; Nazzari, M.; Paonita, A.; Romano, C.; Stagno, V.; et al. Meso-to nano-scale evidence of fluid-assisted co-seismic slip along the normal Mt. Morrone Fault, Italy: Implications for earthquake hydrogeochemical precursors. Earth Planet. Sci. Lett. 2021, 568, 117010. [CrossRef]

26. Barberio, M.D.; Barbieri, M.; Billi, A.; Doglioni, C.; Petitta, M. Hydrogeochemical changes before and during the 2016 AmatriceNorcia seismic sequence (central Italy). Sci. Rep. 2017, 7, 11735. [CrossRef] [PubMed] 
27. Person, M.; Baumgartner, L.; Bos, B.; Connolly, J.; Gratier, J.P.; Gueydan, F.; Miller, S.A.; Rosenberg, C.L.; Urai, J.L.; Yardley, B.W.D. Group report: Fluids, geochemical cycles, and mass transport in fault zones. In Tectonic Faults-Agents of Change on a Dynamic Earth. Report of the 95th Dahlem Workshop on The Dynamics of Fault Zones Berlin, 16-21 January 2005; Handy, M.R., Hirth, G., Hovius, N., Eds.; The MIT Press: Cambridge, MA, USA, 2007; pp. 403-425. Available online: https:/ /www.researchgate.net/publication/ 230561302 (accessed on 24 September 2021).

28. Martinelli, G.; Dadomo, A. Factors constraining the geographic distribution of earthquake geochemical and fluid-related precursors. Chem. Geol. 2017, 469, 176-184. [CrossRef]

29. Skelton, A.; Claesson, L.L.; Wästeby, N.; Andrén, M.; Stockmann, G.; Sturkell, E.; Mörth, C.M.; Stefansson, A.; Tollefsen, E.; Siegmund, H.; et al. Hydrochemical changes before and after earthquakes based on long term measurements of multiple parameters at 2 sites in northern Iceland-A review. J. Geophys. Res. Solid Earth 2019, 124, 2702-2720. [CrossRef]

30. Geological Ministry of China. 1:500,000 Geologic Map of Yunnan Province; Geological Publishing House: Beijing, China, 1966. (In Chinese)

31. Wang, E.; Burchfiel, B.C. Late Cenozoic to Holocene deformation in southwestern Sichuan and adjacent Yunnan, China, and its role in formation of the southeastern part of the Tibetan Plateau. GSA Bull. 2000, 112, 413-423. [CrossRef]

32. Shen, J.; Wang, Y.; Song, F. Characteristics of the active Xiaojiang fault zone in Yunnan, China: A slip boundary for the southeastward escaping Sichuan-Yunnan Block of the Tibetan Plateau. J. Asian Earth Sci. 2003, 21, 1085-1096.

33. Sun, Y.; Zhou, X.; Yan, Y.; Li, J.; Fang, W.; Wang, W.; Liu, Y. Soil Degassing From the Xianshuihe-Xiaojiang Fault System at the Eastern Boundary of the Chuan-Dian Rhombic Block, Southwest China. Front. Earth Sci. 2021, 9, 54. [CrossRef]

34. Wang, Y.; Zhao, C.; Liu, F.; Chen, K.; Ran, H. Research on Relationship between Geochemical Characteristics of Thermal Springs and Seismic Activity in Xiaojiang Fault Zone and its Adjacent Area. J. Seismol. Res. 2014, 37, 228-243. (In Chinese)

35. Zhang, M.; Guo, Z.; Xu, S.; Barry, P.H.; Sano, Y.; Zhang, L.; Halldórsson, S.A.; Chen, A.-T.; Cheng, Z.; Liu, C.-Q.; et al. Linking deeply-sourced volatile emissions to plateau growth dynamics in southeastern Tibetan Plateau. Nat. Commun. 2021, 12, 4157. (In press) [CrossRef]

36. Allen, C.R.; Luo, Z.; Qian, H.; Wen, X.Z.; Zhou, H.; Huang, W. Field study of a highly active fault zone; the Xianshuihe Fault of Southwestern China. Geol. Soc. Am. Bull. 1991, 103, 1178-1199. [CrossRef]

37. Allen, C.R.; Gillespie, A.R.; Han, Y.; Sieh, K.E.; Zhang, B.; Zhu, C. Red River and associated faults, Yunnan Province, China; Quaternary geology, slip rates, and seismic hazard. Geol. Soc. Am. Bull. 1984, 95, 686-700. [CrossRef]

38. Song, F.; Wang, Y.; Yu, W.; Cao, Z.; Shen, X.; Shen, J. The Xiaojiang Active Fault Zone; Seismological Press: Beijing, China, 1998; pp. $1-237$.

39. Wen, X.Z. The uniform-slip method for estimating mean slip-rate of strike-slip fault. J. Earthq. Pred. Res. 1998, 7, 170-182.

40. Tapponnier, P.; Peltzer, G.; Le Dain, A.Y.; Armijo, R.; Cobbold, P. Propagating extrusion tectonics in Asia: New insights from simple experiments with plasticine. Geology 1982, 10, 611-616. [CrossRef]

41. Zhang, C.; Zhang, Y.; Wu, M. Study on relationship between earthquake and Hydro-Geochemistry of groundwater in southern part of North-South earthquake belt in China. J. Geomech 2003, 9, 21-30. (In Chinese)

42. BGMRSP. Regional Geology of Xizang (Tibet) Autonomous Region; Geological Publishing House: Beijing, China, 1993.

43. Chen, Z.; Zhou, X.; Du, J.; Xie, C.; Liu, L.; Li, Y.; Yi, L.; Liu, H.; Cui, Y. Hydrochemical characteristics of hot spring waters in the Kangding district related to the Lushan MS = 7.0 earthquake in Sichuan, China. Nat. Hazards Earth Syst. Sci. 2015, 15, 1149-1156. [CrossRef]

44. Baird, R.B.; Eaton, A.D.; Rice, E.W. Standard Methods for Examination of Water and Wastewater, 23rd ed.; American Public Health Association (APHA); American Water Works Association (AWWA): Camden, NJ, USA; Water Environment Federation (WEF): Washington, DC, USA, 2017.

45. Zhang, Y.; Zhang, L.; Chang, Y.; Fan, Z.; Guo, D. Determining Trace Elements in Rock Samples Containing Refractory Minerals by Pressurize-microwave Inductively Coupled Plasma Mass Spectrometry. Uranium Geol. 2018, 34, 105-111. (In Chinese)

46. Wang, P.; Song, X.; Han, D.; Zhang, Y.; Liu, X. A study of root water uptake of crops indicated by hydrogen and oxygen stable isotopes: A case in Shanxi Province, China. Agric. Water Manag. 2010, 97, 475-482. [CrossRef]

47. Barbieri, M.; Franchini, S.; Barberio, M.D.; Billi, A.; Boschetti, T.; Giansante, L.; Gori, F.; Jónsson, S.; Petitta, M.; Skelton, A.; et al. Changes in groundwater trace element concentrations before seismic and volcanic activities in Iceland during 2010-2018. Sci. Total. Environ. 2021, 793, 148635. [CrossRef]

48. Cao, X.; Wu, P.; Zhou, S.; Han, Z.; Tu, H.; Zhang, S. Seasonal variability of oxygen and hydrogen isotopes in a wetland system of the Yunnan-Guizhou Plateau, southwest China: A quantitative assessment of groundwater inflow fluxes. Hydrogeol. J. 2018, 26, 215-231. [CrossRef]

49. Craig, H. Isotopic variations in meteoric waters. Science 1961, 133, 1702-1703. [CrossRef]

50. Giggenbach, W.F. Isotopic shifts in waters from geothermal and volcanic systems along convergent plate boundaries and their origin. Earth Planet. Sci. Lett. 1992, 113, 495-510. [CrossRef]

51. Yan, R.; Guan, Z.; Liu, Y. Hot spring water observations and its anomalies before the Lushan MS7.0 earthquake in the western Sichuan region. Acta Seismol. Sin. 2015, 37, 347-356.

52. Liu, J.; Song, X.; Yuan, G.; Sun, X.; Liu, X.; Wang, S. Characteristics of atmospheric precipitation $\delta^{18} \mathrm{O}$ in Eastern China and the origin of water vapor. Sci. China Press 2009, 54, 3521-3531. (In Chinese) 
53. Boschetti, T.; Cifuentes, J.; Iacumin, P.; Selmo, E. Local meteoric water line of Northern Chile (18 S-30 S): An application of error-in-variables regression to the oxygen and hydrogen stable isotope ratio of precipitation. Water 2019, 11, 791. [CrossRef]

54. Apollaro, C.; Vespasiano, G.; Muto, F.; De Rosa, R.; Barca, D.; Marini, L. Use of mean residence time of water, flowrate, and equilibrium temperature indicated by water geothermometers to rahnk geothermal resources. Application to the thermal water circuits of Northern Calabria. J. Volcanol. Geotherm. Res. 2016, 328, 147-158. [CrossRef]

55. Zhao, K.; Jang, G.; Yang, Y.; Liu, D.; Liu, Y.; Wang, L. Brief analysis of the reasons of $\mathrm{CO}_{2}$ Degassing from hot springs on main faults within the east of Yunnan. Earth Environ. 2005, 33, 11-15.

56. Aiuppa, A.; Dongarra, G.; Capasso, G.; Allard, P. Trace elements in the thermal groundwaters ofVulcano Island (Sicily). J. Volcanol. Geotherm. Res. 2000, 98, 189-207. [CrossRef]

57. Chen, Q.; Yu, S.; Wen, H.; Lan, J.; Luo, C. A Preliminary Study on the Possible Mechanism of Enrichment and Occurrence State of $\mathrm{Nb}-\mathrm{Ga}-\mathrm{REE}$ in the Emeishan Basalts from the Diandong Qianxi Region. Bull. Mineral. Petrol. Geochem. 2020, 39, 1256-1277. (In Chinese)

58. Cai, C.; Franks, S.G.; Aagaard, P. Origin and migration of brines from Paleozoic strata in Central Tarim, China: Constraints from 87Sr/86Sr, $\delta \mathrm{D}, \delta 18 \mathrm{O}$ and water chemistry. Appl. Geochem. 2001, 16, 1269-1284. [CrossRef]

59. Giggenbach, W.F. Geothermal solute equilibria: Derivationof Na-K-Ma-Ca geoindicators. Geochim. Et Cosmochim. Acta 1988, 52, 2749-2765. [CrossRef]

60. Fournier, R.O.; Truesdel, A.H. Empirical Na-K-Ca geothermometer for natural waters. Geochim. Cosmochim. Acta 1973, 37, 1255-1275. [CrossRef]

61. Proceedings of the Second United Nations symposium on the development and use of geothermal resources. Available online: https: / / www.osti.gov/biblio/7315693-proceedings-second-united-nations-symposium-development-use-geothermalresources-volume (accessed on 24 September 2021).

62. Fournier, R.O.; Potter, R.W. Magnesium correction to the Na-K-Ca chemical geothermometer. Geochim. Et Cosmochim. Acta. 1979, 43, 1543-1550. [CrossRef]

63. Tonani, F. Some remarks on the application of geochemical techniques in geothermal exploration. In Advances in European Geothermal Research; Springer: Dordrecht, The Netherlands, 1980; pp. 428-443.

64. Fouillac, C.; Micard, G. Sodium/Lithium ratios in water applied to geothermetry of geothermal reservoirs. Geothermics 1981, 10, 55-70. [CrossRef]

65. Fournier, R.O.; Potter, R.W. A revised and expanded silica (quartz) geothermometer. Geoth. Res. Counc. Bull. 1982, 11, 3-9.

66. Arnórsson, S. Chemical equilibria in icelandic geothermal systems-Implications for chemical geothermometry investigations. Geothermics 1983, 12, 119-128. [CrossRef]

67. Chiodini, G.; Frondini, F.; Marini, L. Theoretical geothermometers and pCO2 indicators for aqueous solutions coming from hydrothermal systems of medium-low temperature hosted in carbonate-evaporite rocks. Application to the thermal springs of the Etruscan Swell. Italy. Appl. Geochem. 1995, 10, 337-346. [CrossRef]

68. Zheng, X.; Guo, J. Silica geothermal temperature scale and its related problems. Ground Water 1996, 18, 85-88. (In Chinese)

69. Pang, Z. Used the $\mathrm{SiO}_{2}$ mixing model to calculate Zhangzhou geothermal heat storage temperature. Chin. Sciense Bull. 1990, 35, 57-59. (In Chinese)

70. Deutsch, W.J. Groundwater Geochemistry: Fundamentals and Applications to Contamination; Lewis Publisher: New York, NY, USA, 1997.

71. Rouabhia, A.; Djabri, L.; Hadji, R.; Baali, F.; Fahdi, C.; Hanni, A. Geochemical characterization of groundwater from shallow aquifer surrounding Fetzara Lake NE Algeria. Arab. J. Geosci. 2012, 5, 1-13. [CrossRef]

72. Wang, C.Y.; Manga, M. Hydrologic responses to earthquakes and a general metric. Geofluid 2010, 10, $206-216$.

73. Toutain, J.P.; Munoz, M.; Poitrasson, F.; Lienard, A.C. Springwater chloride ion anomaly prior to a $M_{L}=5.2$ Pyrenean earthquake. Earth Planet. Sci. Lett. 1997, 149, 113-119. [CrossRef]

74. Li, B.; Shi, Z.; Wang, G.; Liu, C. Earthquake-related hydrochemical changes in thermal springs in the Xianshuihe Fault zone. West. China J. Hydrol. 2020, 579, 124175. [CrossRef]

75. Thomas, D. Geochemical precursors to seismic activity. Pure Appl. Geophys. 1988, 126, 241-266. [CrossRef]

76. Cox, S.C.; Menzies, C.D.; Sutherland, R.; Denys, P.H.; Teagle, D.A.H. Changes in hot spring temperature and hydrogeology of the Alpine Fault hanging wall, New Zealand, induced by distal South Island earthquakes. Geofluids 2015, 15, 216-239. [CrossRef]

77. Ranjram, M.; Gleeson, T.; Uijendijk, E. Is the permeability of crystalline rock in the shallow crust related to depth, lithology or tectonic setting? Geofluids 2015, 15, 106-119. [CrossRef]

78. Claesson, L.; Skelton, A.; Graham, C.; Moerth, C.M. The timescale and mechanisms of fault sealing and water-rock interaction after an earthquake. Geofluids 2007, 7, 427-440. [CrossRef]

79. Quattrocchi, F.; Pik, R.; Pizzino, L.; Guerra, M.; Lombardi, S. Geochemical changes at the Bagni di Triponzo thermal spring during the Umbria-Marche 1997-1998 seismic sequence. J. Seism. 2000, 4, 567-587. [CrossRef]

80. Mahmoudi, N.; Nakhaei, M.; Porhemmat, J. Assessment of hydrogeochemistry and contamination of Varamin deep aquifer, Tehran Province, Iran. Environ. Earth Sci. 2017, 76, 370. [CrossRef]

81. Wang, M.; Shen, Z.K. Present-day crustal deformation of continental China derived from GPS and its tectonic implications. J. Geophys. Res. Solid Earth 2020, 125, e2019JB018774. [CrossRef]

82. Ma, J. On "whether earthquake precursors help for prediction do exist". Chin. Sci. Bull. 2016, 61, 409-414. (In Chinese) [CrossRef] 
83. Cicerone, R.D.; Ebel, J.E.; Britton, J. A systematic compilation of earthquake precursors. Tectonophysics 2009, 476, 371-396. [CrossRef]

84. Crampin, S.; Gao, Y.; Bukits, J. A review of retrospective stress-forecasts of earthquakes and eruptions. Phys. Earth Planet. Inter. 2015, 24, 76-87. [CrossRef]

85. Zhou, X.; Yan, Y.; Fang, W.; Wang, W.; Shi, H.; Li, P. Short-Term Seismic Precursor Anomalies of Hydrogen Concentration in Luojishan Hot Spring Bubbling Gas, Eastern Tibetan Plateau. Front. Earth Sci. 2021, 8, 586279. [CrossRef]

86. Martinelli, G.; Tamburello, G. Geological and Geophysical Factors Constraining the Occurrence of Earthquake Precursors in Geofluids: A Review and Reinterpretation. Front. Earth Sci. 2020, 8, 596050. [CrossRef]

87. Bai, D.; Unsworth, M.J.; Meju, M.A.; Ma, X.; Teng, J.; Kong, X.; Sun, Y.; Sun, J.; Wang, L.; Jiang, C.; et al. Crustal deformation of the eastern Tibetan plateau revealed by magnetotelluric imaging. Nat. Geosci. 2010, 3, 358-362. [CrossRef]

88. Zhou, X.; Wang, W.; Chen, Z.; Yi, L.; Liu, L.; Xie, C.; Cui, Y.; Du, J.; Cheng, J.; Yang, L. Hot Spring Gas Geochemistry in Western Sichuan Province, China After the Wenchuan Ms 8.0 Earthquake. Terr. Atmos. Ocean. Sci. 2015, 26, 361-373. [CrossRef]

89. Zhang, M.; Zhou, X.; Caracausi, A.; Sano, Y.; Guo, Z.; Zheng, G.; Lang, Y.; Liu, C. Deciphering a mantle degassing transect related with India-Asia continental convergence from the perspective of volatile origin and outgassing. Geochim. Et Cosmochim. Acta 2021, 310, 61-78. [CrossRef] 